PRELIMINARY INTERPRETIVE REPORT 2014-2

COOK INLET PROGRAM 2013 FIELD STUDIES: OBSERVATIONS AND PRELIMINARY INTERPRETATIONS FROM NEW 1:63,360-SCALE GEOLOGIC MAPPING OF THE INISKIN PENINSULA, LOWER COOK INLET, ALASKA

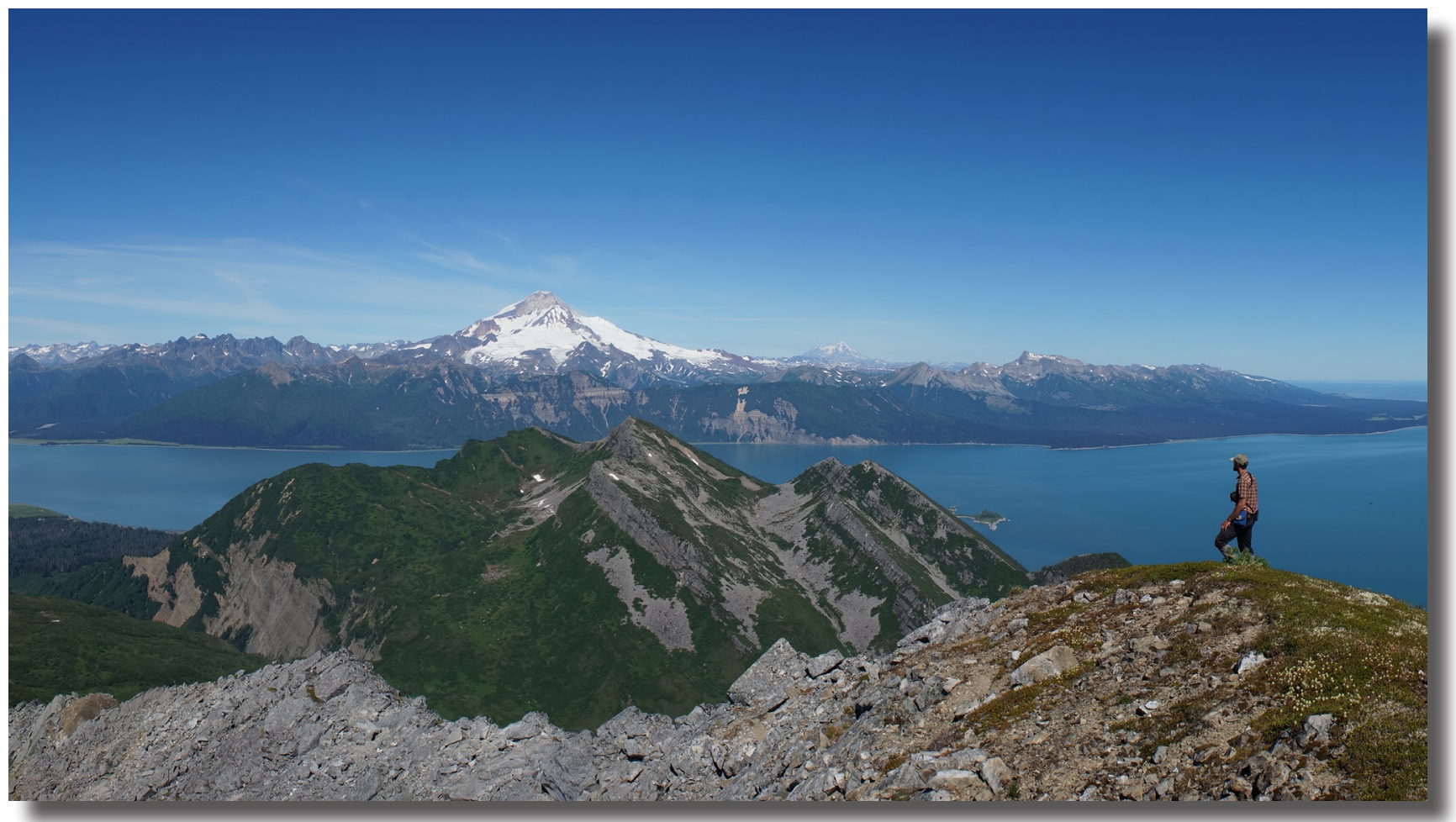

DGGS Geologist Trystan Herriott gazing northward across the Tilted Hills, Iniskin Peninsula; Iliamna Volcano is in the background. Photo by Marwan Wartes.

June 2014

Released by

STATE OF ALASKA

DEPARTMENT OF NATURAL RESOURCES

Division of Geological \& Geophysical Surveys 



\section{CONTENTS}

COOK INLET PROGRAM 2013 FIELD STUDIES: Observations and preliminary interpretations from new

1:63,360-scale geologic mapping of the Iniskin Peninsula, lower Cook Inlet, Alaska 1

Robert J. Gillis, Editor

\section{CHAPTER 1}

Overview of new 1:63,360-scale geologic mapping of the Iniskin Peninsula, lower Cook Inlet, Alaska.. 3

Robert J. Gillis, Marwan A. Wartes, Trystan M. Herriott, Katharine F. Bull, Paul L. Decker, and Paul M. Betka

\section{CHAPTER 2}

Brief overview of geologic mapping of the Middle Jurassic Chinitna Formation and Upper Jurassic

Naknek Formation in the Tilted Hills, Iniskin Peninsula, Cook Inlet, Alaska.

Trystan M. Herriott and Marwan A. Wartes

\section{CHAPTER 3}

Preliminary observations: A facies architecture study of the Lower Jurassic Talkeetna Formation, Iniskin

Peninsula, Alaska

Katharine F. Bull

\section{CHAPTER 4}

Preliminary kinematic evidence for right-lateral slip along a system of steeply-dipping faults in the hanging wall of the Bruin Bay fault, Iniskin Peninsula, lower Cook Inlet, Alaska.....

Paul M. Betka and Robert J. Gillis

\section{CHAPTER 5}

A new occurrence of oil-stained rocks within a small fault zone involving the Middle Jurassic Cynthia

Falls Formation, Tuxedni Group, northern Iniskin Peninsula.

Marwan A. Wartes and Trystan M. Herriott

\section{CHAPTER 6}

Discovery of oil-stained sandstone within the Chinitna Formation, northern Iniskin Peninsula

Marwan A. Wartes and Trystan M. Herriott

\section{FIGURES}

Figure 1-1. Generalized geologic map of lower western Cook Inlet, showing the location of 1:63,360-scale geologic mapping of the Iniskin Peninsula in 2013, and planned geologic mapping in 2014-2015

1-2. Comparison of a simplified preliminary inch-to-mile geologic map of the Iniskin Peninsula constructed from data collected during the 2013 DGGS mapping campaign with an excerpt of the 1966 inch-to-mile geologic map of Detterman and Hartsock for same area .....

1-3. SPOT 5 satellite image of the Iniskin Peninsula, showing approximate map outline, locations of field stations, and zone of exclusion from mapping by the landholders along the hinge of the Fitz Creek anticline. 
2-1. Index map of the Iniskin Peninsula area .....

2-2. View eastward of Chinitna and Naknek Formations of the Iniskin Peninsula's Tilted Hills, with the east shore of Iniskin Bay in the foreground

2-3. Simplified geologic map of the Tilted Hills ......

2-4. Mappable characteristics of Chinitna and Naknek Formation members, with view southeastward of an unnamed mountain northeast of Front Mountain

2-5. View southwestward of Cy Peak and Shark Tooth Hill area, exhibiting typical weathering profiles of Paveloff through Pomeroy Arkose members

3-1. Location of Iniskin Peninsula map area, and approximate location of the Talkeetna Arc west and northwest of Cook Inlet.

3-2. Photos showing mafic to intermediate lava underlain by blocky monomictic breccia, Marsh-Portage Creek member, and monomictic breccia containing tightly packed, rotated, flow-banded clasts

3-3. Thinly bedded volcaniclastic siltstones and very-fine- to fine-grained sandstones in the Marsh-Portage Creek member in two coastal outcrops.

4-1. Simplified preliminary inch-to-mile geologic map of the Iniskin Peninsula constructed from data collected during the 2013 DGGS mapping campaign

4-2. Panoramic view looking northwest showing the outcrop extent of Triassic(?) marble (Trm) in the map area

4-3. View looking west-southwest showing map trace of the southwestern contact of the Triassic marble with the Talkeetna Formation....

4-4. Fault-zone cataclasite contained in the Triassic marble unit, and fault surface that contains slip lineations defined by calcite slicken fibers and fault plane mullions

4-5. Synthesis of fault-slip data from 17 minor fault surfaces collected in the fault zone in the vicinity of figure 4-4

5-1. Location map of southern Alaska, shaded-relief map of western Cook Inlet, and geologic map of the northern Iniskin Peninsula.

5-2. Outcrop photo of the oil-stained fault zone.

5-3. View to the southwest illustrating the approximate location of the oil-stained fault zone in the southeast-dipping limb of the Fitz Creek anticline

6-1. Shaded-relief location map of southern Alaska and simplified geologic map of the Tilted Hills on the Iniskin Peninsula

6-2. Annotated photo of the northern Tilted Hills on the Iniskin Peninsula. 


\title{
COOK INLET PROGRAM 2013 FIELD STUDIES: OBSERVATIONS AND PRELIMINARY INTERPRETATIONS FROM NEW 1:63,360-SCALE GEOLOGIC MAPPING OF THE INISKIN PENINSULA, LOWER COOK INLET, ALASKA
}

\begin{abstract}
Robert J. Gillis ${ }^{1}$, editor
Ongoing field studies by the Alaska Division of Geological \& Geophysical Surveys (DGGS) for the Cook Inlet basin analysis program focused on new 1:63,360-scale geologic mapping of the Iniskin Peninsula, lower Cook Inlet, in summer 2013. The Iniskin Peninsula was the location of some of the earliest oil exploration in Alaska, due largely to the presence of several hydrocarbon seeps discovered there. Mesozoic strata that are well exposed on the peninsula also host the source rock for oil in the producing Cenozoic interval in the basin. Yet despite abundant evidence for thermal maturation and migration of liquid hydrocarbons in the area, the region has remained under explored, and the geology lightly studied for nearly 50 years. Reconnaissance outcrop studies in the area by DGGS and collaborators from the Alaska Division of Oil \& Gas (DOG), and the U.S. Geological Survey (USGS) since 2009 have focused on more thoroughly understanding the stratigraphy, reservoir quality, and structural geometries in lower Cook Inlet. Our findings have highlighted the need to revise the current geologic map of the peninsula. The goal of new 1:63,360-scale geologic mapping is not only to more accurately portray the distribution of rock units and geologic structures along the western margin of the basin, but also to promote a better understanding of lateral facies changes and structural geometries that relate to the distribution of potential reservoir facies and occurrences of hydrocarbon traps.
\end{abstract}

The following short reports are intended to promptly disseminate preliminary observations and key findings about the geologic framework of the Iniskin Peninsula region and evolution of the Mesozoic forearc basin to the public, and are to be followed by more comprehensive interpretive reports and data in the near future. The report volume begins with a discussion about the geologic mapping project objectives, and methods by which they were completed. Subsequent reports in this volume focus on specific aspects of the geology that provide new insights into the stratigraphic and structural controls that affect the hydrocarbon potential of the Cook Inlet forearc basin, including:

- An overview of new inch-to-mile (1:63,360-scale) mapping of the Iniskin Peninsula, highlighting major revisions to the previous mapping (chapter 1).

- Mapping constraints for the Tilted Hills and fundamental stratigraphic characteristics used to define members of the Chinitna and Naknek Formations (chapter 2).

- Stratigraphic characteristics and depositional environment for Talkeetna Formation volcaniclastic and volcanic rocks. Combining of the Marsh Creek Breccia and Portage Creek Agglomerate members into the Marsh-Portage Creek Member (chapter 3).

- Kinematic analyses of a high-angle fault in the hanging wall of the Bruin Bay fault and potential implications for slip along the Bruin Bay fault system (chapter 4).

- A discussion of a newly recognized oil-stained exposure hosted entirely within the damage zone of a fault cutting the Cynthia Falls Formation (chapter 5).

- A discussion of a newly recognized zone of oil-saturated rock hosted by primary porosity within Paveloff Formation sandstone (chapter 6).

\section{ACKNOWLEDGMENTS}

We thank Rebekah Tsigonis for field assistance and camp support; Rick Stanley (U.S. Geological Survey) and Ken Helmold (Alaska Division of Oil \& Gas) for constructive conversations in the field; Mike Fell (Pathfinder Aviation) for helicopter support; Merril and Marti (Bear Mountain Lodge) for their hospitality; Jack Barber (Alaska Air Taxi); Bald Mountain Air; and David LePain for careful review of this report. The Iniskin Peninsula area mapping project was funded by a substantial contribution from the U.S. Geological Survey STATEMAP Program (award no. G13AC00157).

${ }^{1}$ Alaska Division of Geological \& Geophysical Surveys, 3354 College Rd., Fairbanks, Alaska 99709-3707; robert.gillis@alaska.gov 



\section{CHAPTER 1}

\section{OVERVIEW OF NEW 1:63,360-SCALE GEOLOGIC MAPPING OF THE INISKIN PENINSULA, LOWER COOK INLET, ALASKA}

Robert J. Gillis ${ }^{1}$, Marwan A. Wartes ${ }^{1}$, Trystan M. Herriott ${ }^{1}$, Katharine Bull², Paul L. Decker ${ }^{3}$, and Paul M. Betka ${ }^{1}$

The Alaska Division of Geological \& Geophysical Surveys (DGGS) and the Alaska Division of Oil and Gas conducted new inch-to-mile (1:63,360-scale) geologic mapping of approximately 235 square miles on the Iniskin Peninsula and adjacent area in summer 2013 (fig. 1-1). The project was part of DGGS's Cook Inlet basin analysis program that has focused on geologic components of Cook Inlet petroleum systems since 2006, initially in the producing Cenozoic stratigraphy.

In 2009, our field investigations transitioned toward the less-well-understood Mesozoic strata, which features oil seeps in several locations and contains the source interval for the trapped oil that is being extracted from the Cook Inlet basin today. The map area straddles the margin of the Early to Late Jurassic Talkeetna arc-forearc basin system and encompasses a relatively complete, but structurally dissected, crustal section from the arc roots upward through the arc edifice into the clastic basin fill. The arc complex has been exhumed against the forearc basin in the hanging wall of the regional-scale, northwest-dipping Bruin Bay fault system and consists mainly of Early to early Middle Jurassic granitoids and Lower Jurassic volcanic and volcaniclastic rocks. The footwall of the fault system bounding the forearc basin is composed of a $>4,800$-m-thick succession of Middle to Upper Jurassic marine strata that are folded by a large syncline-anticline pair. Thus the map area provides opportunities to understand changes in the Jurassic stratigraphy through time, relations between hydrocarbon migration and structural trap formation, and more generally, the geologic evolution of the basin.

The most current understanding of the geology of the Iniskin Peninsula area and Cook Inlet Mesozoic stratigraphy comes principally from studies by the U.S. Geological Survey from 1944 to 1958 that were published in a series of reports and maps (for example, Kellum, 1945; Kirschner and Minard, 1949; Hartsock, 1954; Juhle, 1955; Grantz, 1956) and culminated in the seminal 1:63,360-scale compilation geologic map and accompanying report (Detterman and Hartsock, 1966). Whereas this body of work is extensive in both breadth and detail, our work on the peninsula and surrounding areas since 2009 has highlighted the need to revise the mapping to (1) document more accurately how stratigraphic units laterally wedge out across the map area (chapter 2, this volume), (2) provide a simplified Lower Jurassic volcanic arc stratigraphy based on lithofacies associations (chapter 3, this volume), (3) establish new age assignments for several igneous units, (4) constrain the distribution and type of structures associated with the Bruin Bay fault system (chapter 4, this volume), and (5) record the distribution and density of cross-faults cutting the forearc strata.

Figures 1-2A-B compare the most current published map of Detterman and Hartsock (1966) and a simplified, preliminary version of new mapping conducted in 2013. Notable differences in map interpretations include:

- Northeastward pinch-out of the Chisik Conglomerate Member of the Naknek Formation clearly is present west of Oil Bay, $\sim 7$ miles $(\sim 11.5 \mathrm{~km})$ southwest of where it was formerly mapped (chapter 2 , this volume).

- Marsh Creek Breccia and Portage Creek Agglomerate members of the Talkeetna Formation exhibit indistinguishable lithofacies associations and are tentatively combined into the Marsh-Portage Creek member (Jtkl of fig. 1-2a), whereas the Horn Mountain Tuff Member has been retained (Jtku of fig. 1-2A) (chapter 3, this volume).

- The areal extent of the unnamed Triassic metamorphic unit from Detterman and Hartsock (1966) has been greatly reduced, and work is ongoing to determine its age in the map area.

- Ages of several igneous exposures have been reassigned based on new ${ }^{40} \mathrm{Ar} /{ }^{39} \mathrm{Ar}$ geochronologic results. For example, a Tertiary lava (Tf) mapped to the northwest of the Bruin Bay fault has been identified to be Jurassic in age and is now interpreted as a hypabyssal intrusive. The areal extent of this unit has also been significantly reduced.

- The Bruin Bay fault is tentatively interpreted as a right-stepping transpressional system with two overlapping strands that breach the surface. This interpretation is in contrast to the single fault mapped by Detterman and Hartsock (1966) that exhibits a sharp right jog at Chinitna Bay. The new interpretation is largely consistent with an earlier interpretation of the structure by Hartsock (1954).

\footnotetext{
${ }^{1}$ Alaska Division of Geological \& Geophysical Surveys, 3354 College Rd., Fairbanks, Alaska 99709-3707; robert.gillis@alaska.gov; marwan.wartes@alaska.gov; trystan.herriott@alaska.gov; paul.betka@alaska.gov

${ }^{2}$ Exploration Unlimited, P.O. Box 81418, Fairbanks, Alaska 99708-1418; kfbull@gmail.com

${ }^{3}$ Alaska Division of Oil and Gas, 550 W 7th Ave., Ste. 1100, Anchorage, AK 99501-3560; paul.decker@alaska.gov
} 


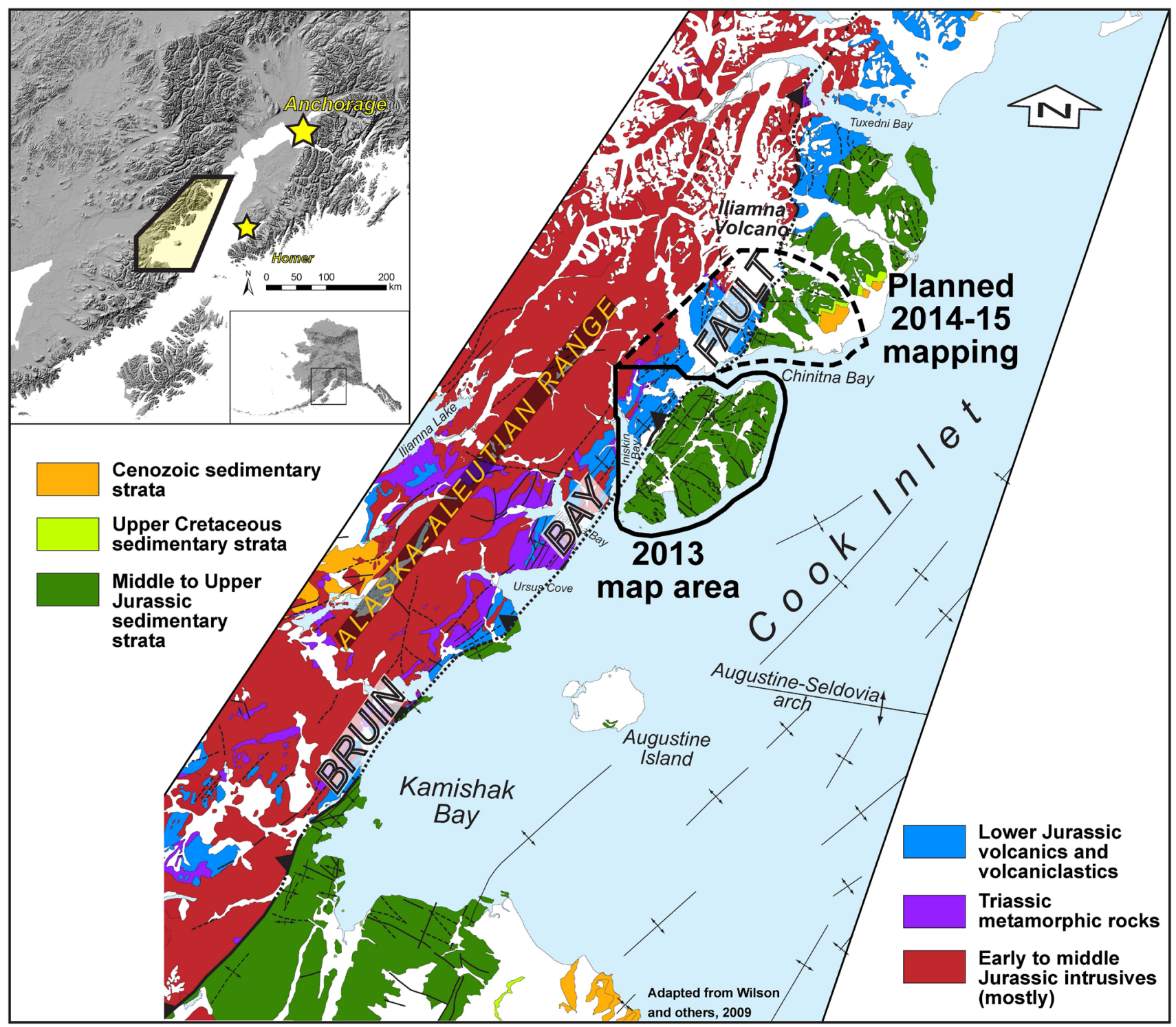

Figure 1-1. Generalized geologic map of lower western Cook Inlet, showing the location of 1:63,360-scale geologic mapping of the Iniskin Peninsula (solid outline) in 2013, and planned geologic mapping in 2014-2015 (dashed outline). Adapted from Wilson and others (2009). Inset shows location of map area in southern Alaska.

- The number of faults that were mapped by Detterman and Hartsock (1966) in the hanging wall of the Bruin Bay fault system has been reduced. Detailed kinematic analyses of one steeply northwest-dipping fault indicates predominantly dextral motion (chapter 4, this volume), in contrast to the several kilometers of sinistral reverse motion interpreted for the fault system in earlier studies (for example, Detterman and Hartsock, 1966; Detterman and Reed, 1980).

- The density and extent of numerous previously-mapped, northwest-striking cross-faults cutting footwall strata has been greatly reduced. Many of these formerly recognized faults have distinct topographic expression, but no observed stratigraphic separation. Most of these features are reassigned as fracture lineaments, or omitted altogether.

Our mapping of the Iniskin Peninsula area benefitted from helicopter access to rugged, higher-elevation regions that were either inaccessible or impractical to visit by previous workers. Conversely, the limited distribution of outcrops in the lowerelevation interior regions of the map area hampered mapping stratigraphic and structural relations exposed during previous field studies. As a result, the new map is thought to be greatly improved over earlier efforts in the high country of the Tilted Hills and region northwest of the Bruin Bay fault where stratigraphic and structural relations are well expressed. Perhaps the most significant limitation to mapping was what we speculate to be a substantial encroachment of dense vegetation over the past 50 years that has rendered subtle, yet important, geologic relations unverifiable for parts of the Tonnie syncline and Fitz Creek anticline. Additionally, access to land in part of the core of the Fitz Creek anticline, including many of the 


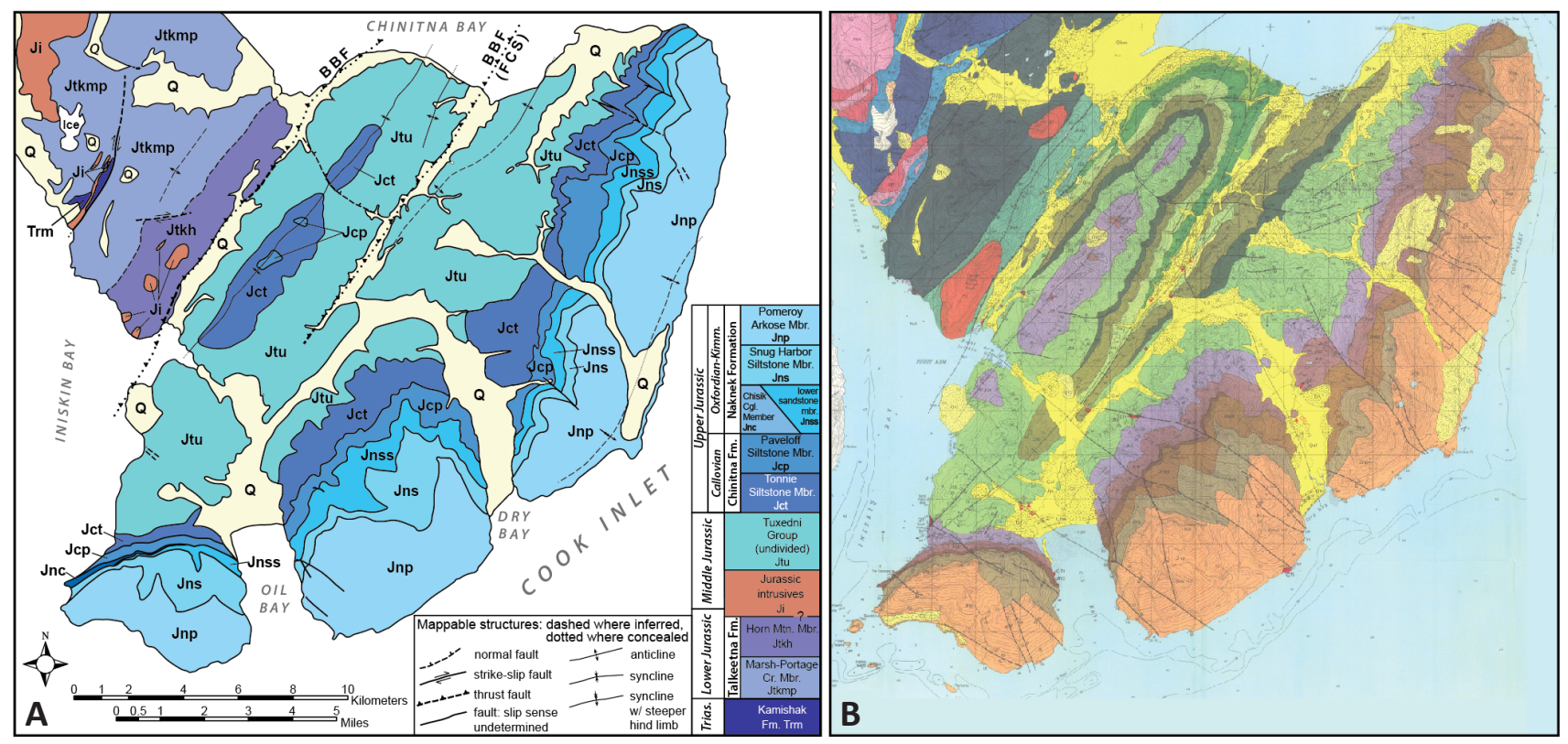

Figure 1-2. Comparison of (A) simplified preliminary inch-to-mile geologic map of the Iniskin Peninsula constructed from data collected during the 2013 DGGS mapping campaign, and (B) excerpt of the inch-to-mile geologic map of Detterman and Hartsock (1966) for same area. Major differences include significant revision of contact locations and position of stratigraphic wedging for the Naknek Formation, simplification of Talkeetna Formation stratigraphy, reinterpretation of Bruin Bay fault as a right-stepping transpressional fault system, simplification of Bruin Bay fault hanging-wall structure, age reassignment and major revision of distribution of hanging-wall intrusive rocks, and delineation of footwall crossfaults from fracture sets. A. Tuxedni Group (Jtu) was mapped in the field, but presented as undivided until completion of aerial photographs and satellite imagery interpretation of lowlands near Iniskin Bay. Stratigraphic contacts defining

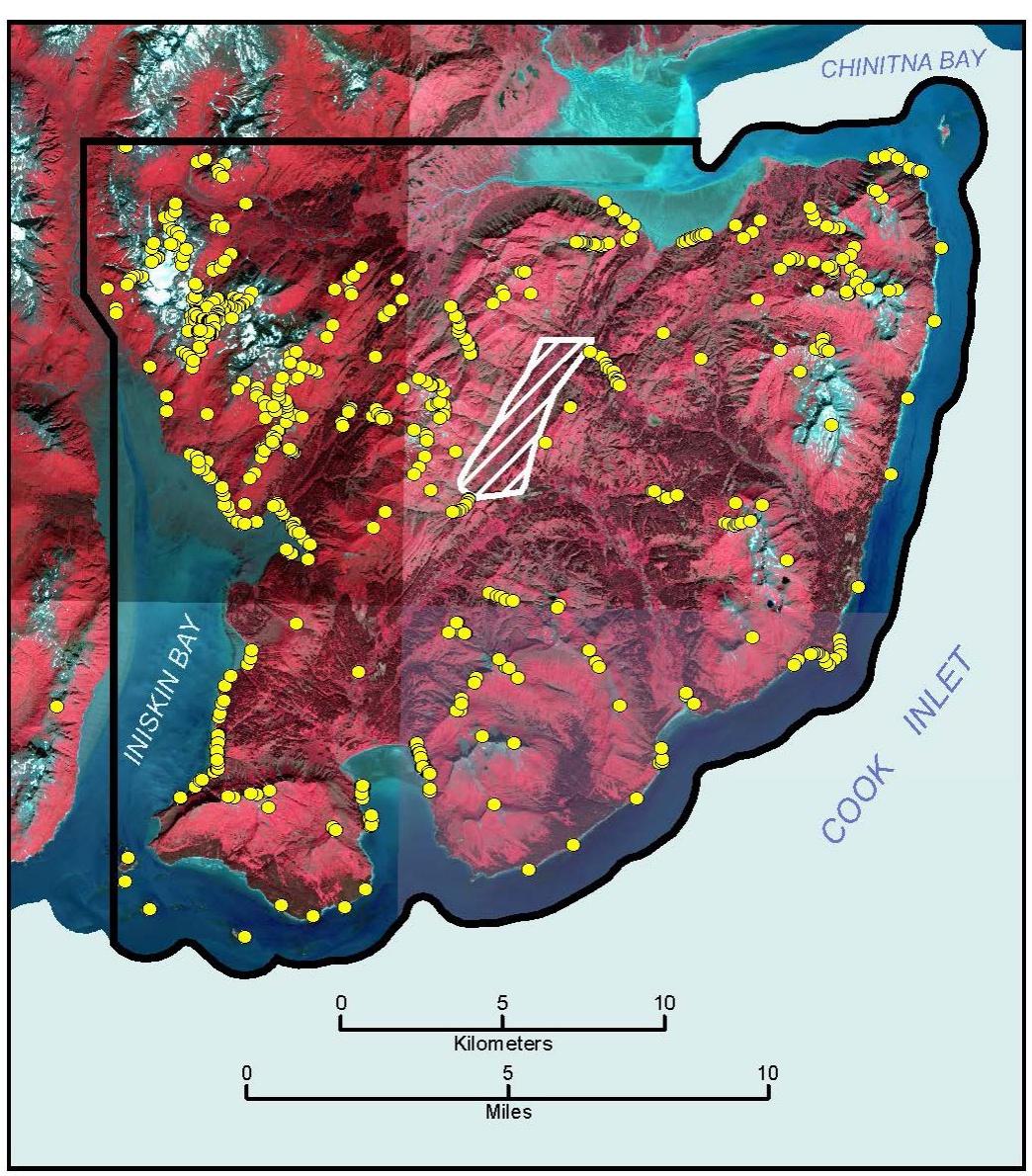
the Fitz Creek anticline and Tonnie syncline will appear on future versions of the map. Quaternary unit provisionally adapted from Detterman and Hartsock (1966). BBF = Bruin Bay fault; FCS = Fitz Creek strand of BBF.

Figure 1-3. SPOT 5 satellite image of the Iniskin Peninsula showing approximate map outline (black polygon), locations of field stations (yellow dots), and zone of exclusion from mapping by the landholders along the hinge of the Fitz Creek anticline (not shown). 
hydrocarbon seeps and historic well sites, was not permitted, prohibiting collection of structural data along that part of the fold axis (fig. 1-3). Efforts are ongoing to supplement the field mapping of the interior portions of the peninsula by using satellite imagery and aerial photographs. Map interpretations made on the basis of these methods will be field checked where possible in 2014. Additional geologic mapping northeast of the Iniskin Peninsula is planned for 2014-15 (fig. 1-1) to develop a better understanding of how sedimentary facies and structural style change along strike of the Jurassic forearc basin margin.

\section{ACKNOWLEDGMENTS}

We thank Rebekah Tsigonis for field assistance and camp support; Rick Stanley (U.S. Geological Survey) and Ken Helmold (Alaska Division of Oil \& Gas) for constructive conversations in the field; Mike Fell (Pathfinder Aviation) for helicopter support; Merril and Marti (Bear Mountain Lodge) for their hospitality; Jack Barber (Alaska Air Taxi); Bald Mountain Air; and David LePain for careful review of this report. The Iniskin Peninsula area mapping project was funded by a substantial contribution from the U.S. Geological Survey STATEMAP Program (award no. G13AC00157).

\section{REFERENCES}

Detterman, R.L., and Hartsock, J.K., 1966, Geology of the Iniskin-Tuxedni region, Alaska: U.S. Geological Survey Professional Paper 512, 78 p., 6 sheets, scale 1:63,360.

Detterman, R.L., and Reed, B.L., 1980, Stratigraphy, structure, and economic geology of the Iliamna quadrangle, Alaska: U.S. Geological Survey Bulletin 1368-B, p. B1-B86, 1 sheet, scale 1:250,000.

Grantz, Arthur, 1956, Magnetite deposits at Tuxedni Bay, Alaska: U.S. Geological Survey Bulletin 1024-D, p. 95-106.

Hartsock, J.K., 1954, Geologic map and structure sections of the Iniskin Peninsula and adjacent area of Alaska: U.S. Geological Survey Open-File Report 54-118, 1 p., 3 sheets.

Juhle, R.W., 1955, Iliamna Volcano and its basement: U.S. Geological Survey Open-File Report 55-77, 141 p., scale 1:96,000.

Kellum, L. B., 1945, Jurassic stratigraphy of Alaska and petroleum exploration in northwest America: New York Acad. Sci. Trans., ser. 2, v. 7, no. 8, p. 201-209.

Kirschner, C.E., and Minard, D.L., 1949, Geology of the Iniskin Peninsula, Alaska: U.S. Geological Survey Oil and Gas Investigations Map 95, 1 sheet, scale 1:48,000.

Wilson, F.H., Hults, C.P., Schmoll, H.R., Haeussler, P.J., Schmidt, J.M., Yehle, L.A., Labay, K.A., and Shew, N.B., 2009, Preliminary integrated geologic map databases for the United States: preliminary geologic map of the Cook Inlet region, Alaska: U.S. Geological Survey Open-File Report 2009-1108. 


\section{CHAPTER 2}

\section{BRIEF OVERVIEW OF GEOLOGIC MAPPING OF THE MIDDLE JURASSIC CHINITNA FORMATION AND UPPER JURASSIC NAKNEK FORMATION IN THE TILTED HILLS, INISKIN PENINSULA, COOK INLET, ALASKA}

Trystan M. Herriott ${ }^{1}$ and Marwan A. Wartes ${ }^{1}$

The Tilted Hills extend for approximately $30 \mathrm{~km}$ along the southeastern Iniskin Peninsula (fig. 2-1) and constitute a physiographically prominent, chiefly northeast-trending belt of peaks, ridges, and areally extensive flat-irons (fig. 2-2). Outcrops in the Tilted Hills dominantly consist of Chinitna and Naknek Formations, permitting examination of latest Middle to Late Jurassic forearc basin strata of Cook Inlet (fig. 2-3). Through detailed documentation of the distribution of lithostratigraphic units in the area we aim to improve our understanding of Jurassic depositional systems in this prolific hydrocarbon-bearing

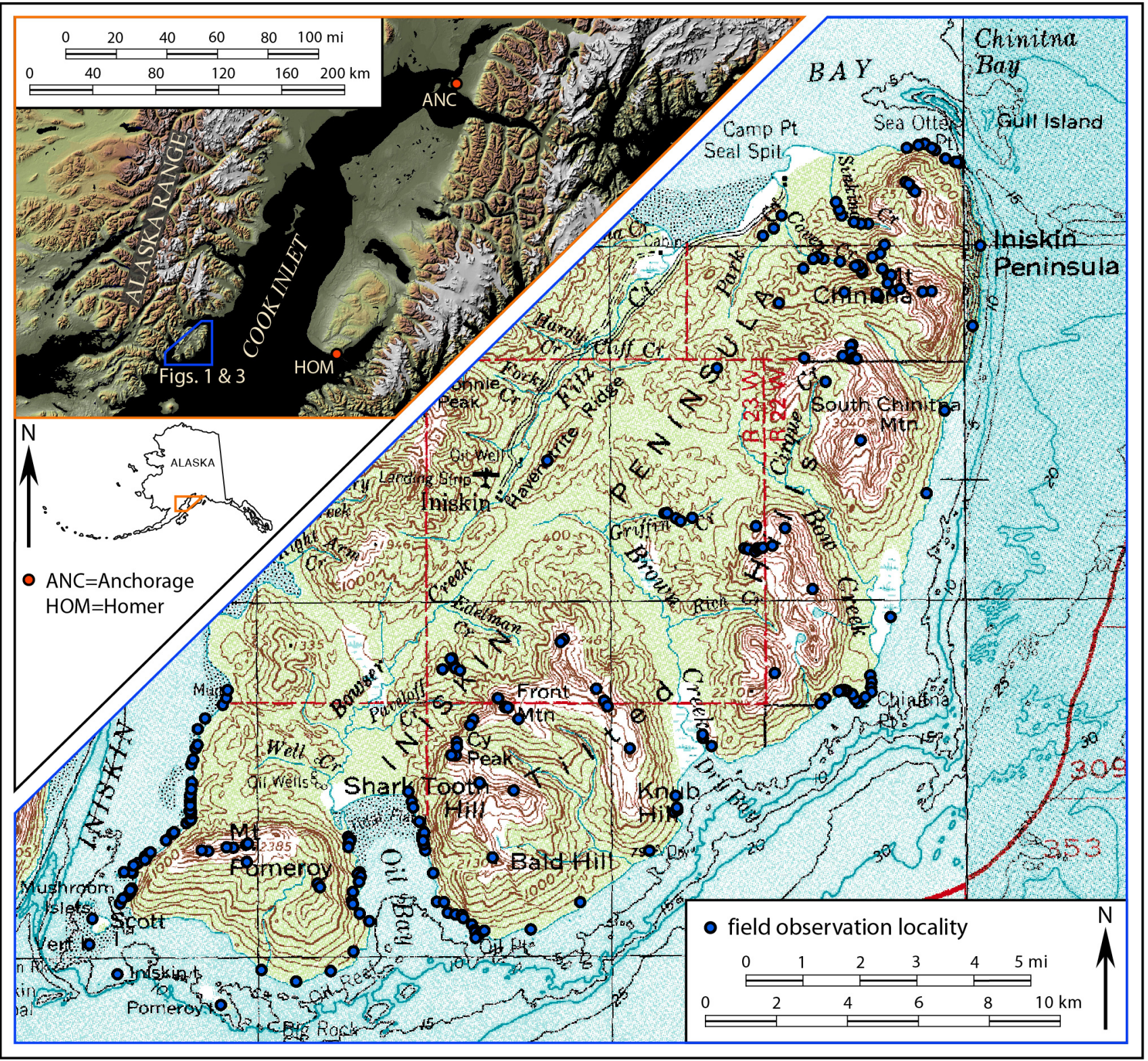

Figure 2-1. Index map of the Iniskin Peninsula area. Detailed observations were made at more than 300 localities during four field seasons in the area. Topographic base map from portions of U.S. Geological Survey Iliamna and Seldovia 1:250,000-scale quadrangles; shaded-relief image modified after U.S. Geological Survey Elevation Data Set Shaded Relief of Alaska poster.

${ }^{1}$ Alaska Division of Geological \& Geophysical Surveys, 3354 College Rd., Fairbanks, Alaska 99709-3707; trystan.herriott@alaska.gov; marwan.wartes@alaska.gov 


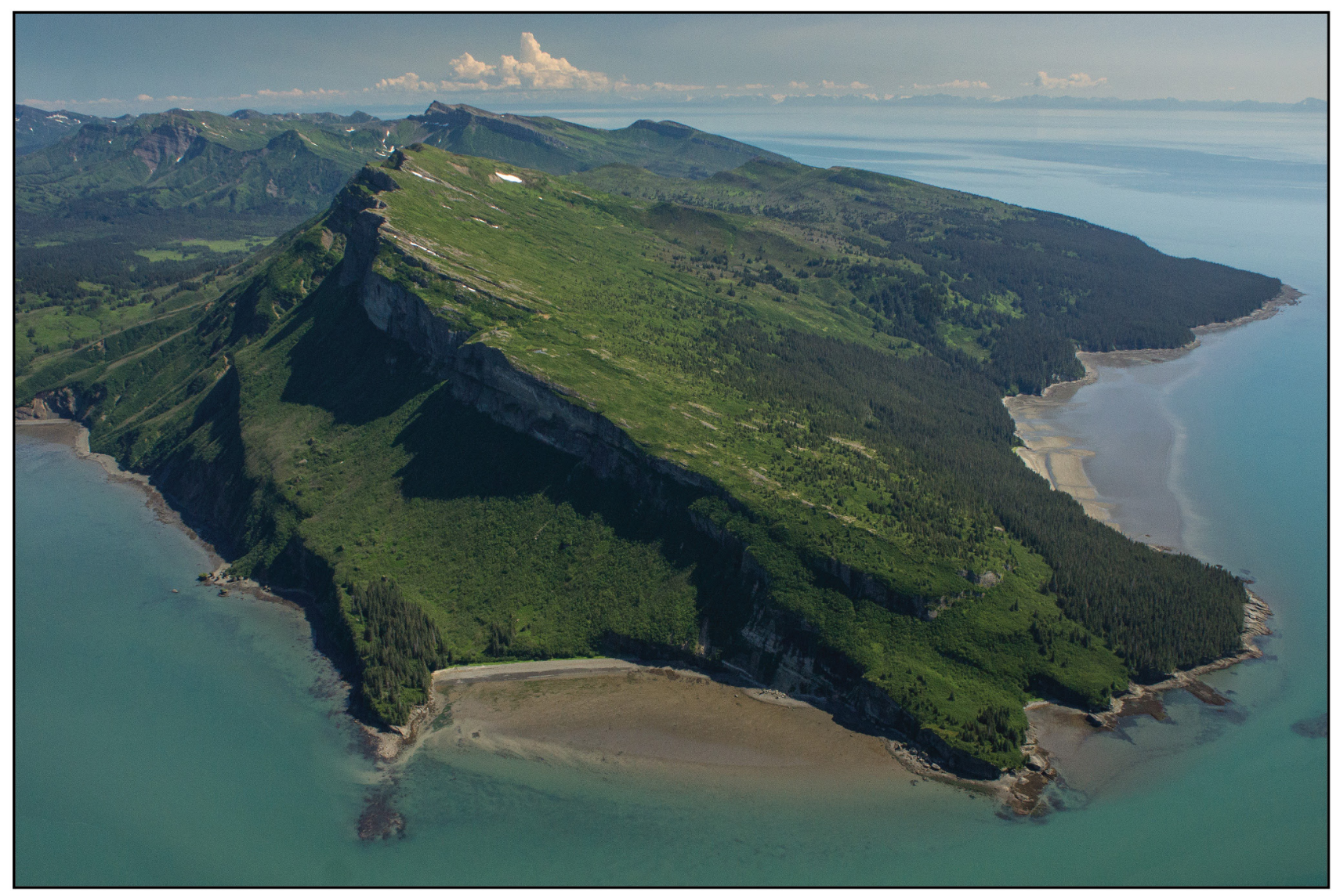

Figure 2-2. View eastward of the Tilted Hills, Iniskin Peninsula, showing the Chinitna and Naknek Formations, with the east shore of Iniskin Bay in the foreground. The largest flat-irons (for example, photo-center) occur in the Pomeroy Arkose Member and the lower part of the vegetated slope below corresponds to the Chinitna Formation.

basin, including key parameters such as accommodation and sediment supply. This brief report presents a simplified version of our 1:63,360-scale geologic map of the Tilted Hills (fig. 2-3) and summarizes some of the mapping criteria that were employed during the 2013 field season. A more thorough summary of our field observations is in the process of being published (Herriott and Wartes, in press [2014]).

The Chinitna and Naknek Formations in the Tilted Hills constitute an approximately 2,000-m-thick section of dominantly marine sandstone and siltstone, with subordinate conglomerate (fig. 2-3). Six mappable members are largely defined by their lithologic character (Detterman and Hartsock, 1966) and are inferred to record sedimentation from fan delta to basin floor depositional environments (LePain and others, 2013; Wartes and others, 2013; Herriott and Wartes, in press [2014]).

The upper Middle Jurassic Tonnie and Paveloff siltstone members (Chinitna Formation) are generally recessive units, with the latter typically exhibiting a slightly more resistant weathering profile (fig. 2-4). Additionally, the two Chinitna members can generally be distinguished by their colors: the Tonnie is characteristically medium-brown-weathering, whereas the Paveloff is chiefly dark-gray-brown- and gray-green-weathering (fig. 2-4). Both of these siltstone units are locally sandy, and Wartes and Herriott (this volume) report an oil-stained locality along Chinitna Bay's south shore (fig.2-1) in the locally well-developed basal sandstone section of the Paveloff.

The basal members of the Upper Jurassic Naknek Formation are the Chisik Conglomerate and lower sandstone (informal) that generally occupy the same stratigraphic position, lying between the Paveloff and Snug Harbor siltstones (fig. 2-3). The commonly boulder-bearing Chisik of this study only occurs in the Iniskin Bay-Mount Pomeroy area (fig.2-1) and stratigraphically transitions into the lower sandstone member approximately $2 \mathrm{~km}$ west of Oil Bay (fig. 2-3). The lower sandstone at Oil Bay is nearly devoid of gravel-sized clasts, and we observed no mappable intertonguing of these units in the Tilted Hills. Both the Chisik and lower sandstone typically exhibit notably more resistant weathering profiles than the underlying Paveloff(fig. 2-5). However, in some exposures, the Paveloff-lower sandstone contact can be somewhat enigmatic where the basal lower sandstone strata do not exhibit a striped color scheme of alternating medium-brown- and light-gray-weathering beds that is common to the unit (fig. 2-4). In such areas, a contact must be correlated to nearby accessible outcrops where 


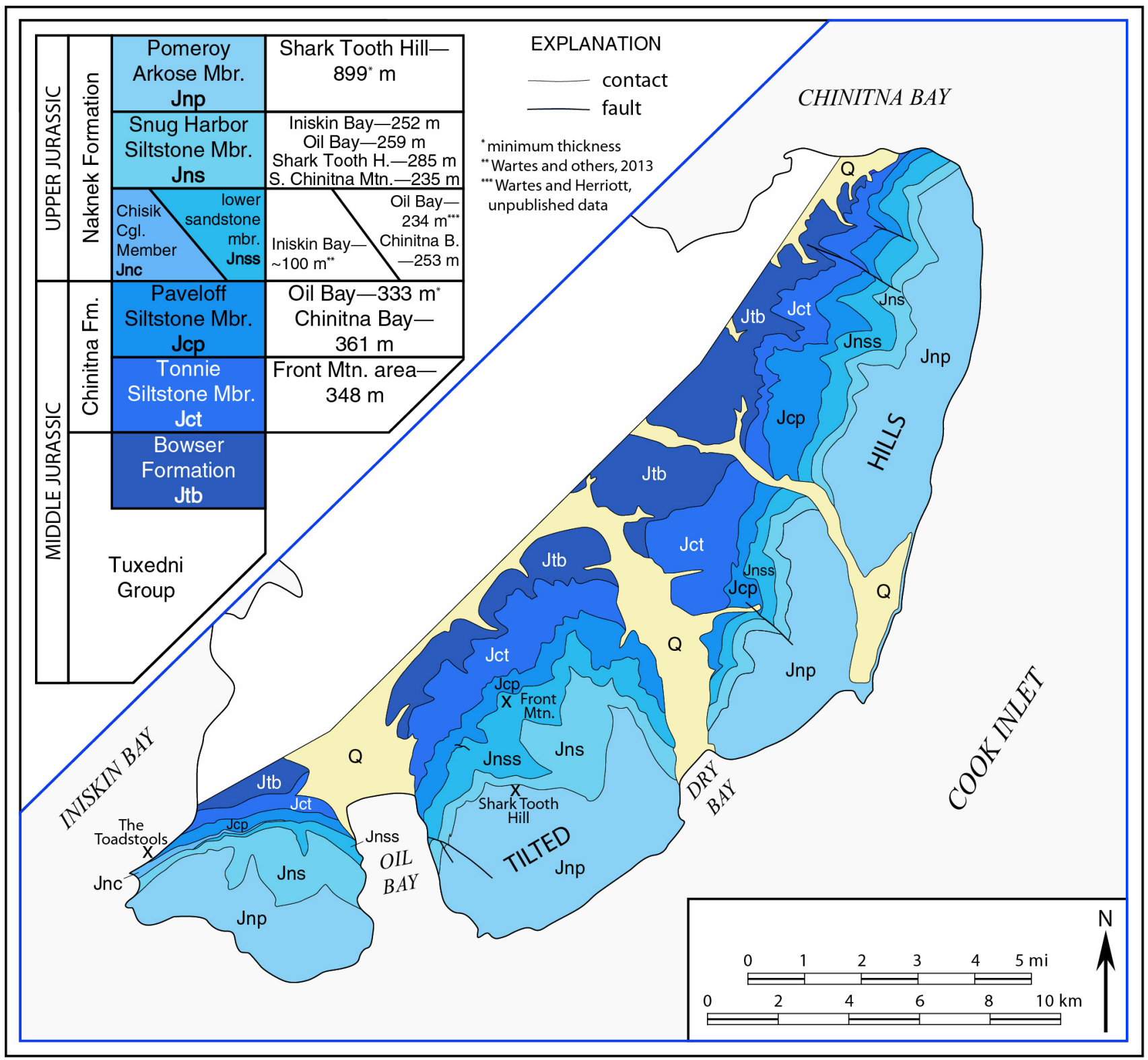

Figure 2-3. Simplified geologic map of the Tilted Hills. This preliminary sketch map is based on 1:63,360-scale mapping completed during the 2013 field season and is part of a larger project focused on mapping the entire Iniskin Peninsula (chapter 1, this volume). Stratigraphic column modified after Detterman and Hartsock (1966). Stratigraphic thicknesses reported are from the current study unless otherwise noted. See figure 2-1 for location index map.

detailed observations of lithofacies, fresh color, and composition can be made: the Paveloff is typically more silt-rich, thinner bedded, greener colored, and less arkosic.

The Chisik and lower sandstone are overlain by the Snug Harbor Siltstone Member (Naknek Formation), with the notable exception of the Mount Pomeroy area where the lower sandstone overlies Chisik (fig. 2-3). The base of the Snug Harbor is commonly readily mappable along an abruptly recessive surface (fig. 2-5). This dark-weathering, fine-grained unit locally contains sandstone beds, and conglomeratic sandstone and conglomerate are minor but notable constituents of the Snug Harbor. Despite being recessive at its base, the Snug Harbor locally crops out within resistant peaks of the Tilted Hills (fig. 2-4).

The Pomeroy Arkose Member (Naknek Formation) forms extensive cuestas and flat-irons (fig. 2-2) and is generally the most conspicuously mappable unit in the Tilted Hills, with the Snug Harbor-Pomeroy contact being mapped along the base of cliff-forming amalgamated arkose (fig. 2-5). The chiefly gray-weathering Pomeroy is dominantly sandstone, although thick packages of siltstone as well as conglomerate are observed. The top of the unit is not exposed in the map area. 


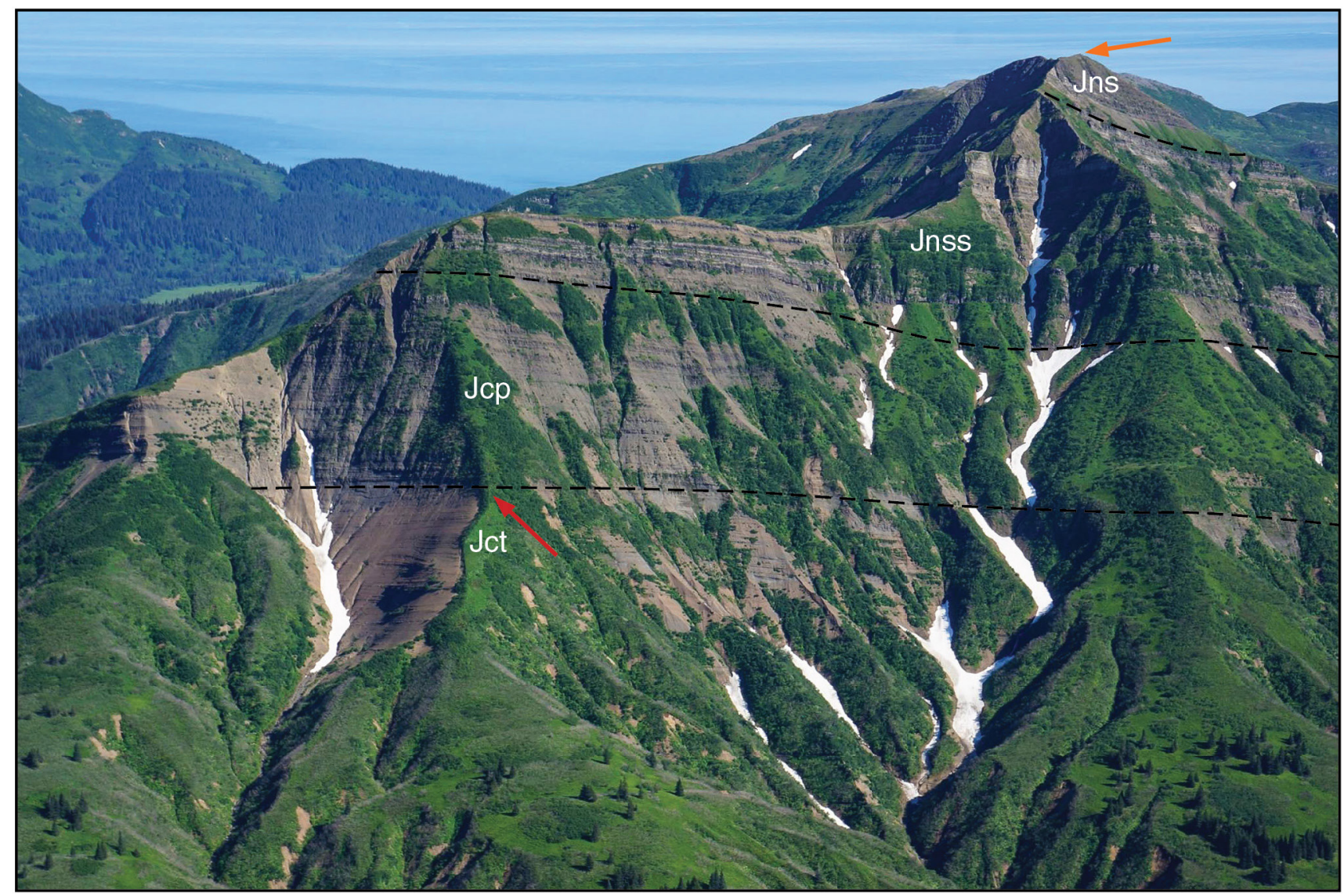

Figure 2-4. Mappable characteristics of Chinitna and Naknek Formation members, with view southeastward of an unnamed mountain northeast of Front Mountain (figs. 2-1 and 2-3). The medium-brown-weathering color of Tonnie (Jct) contrasts well against the dark-gray-brown-weathering color of the overlying Paveloff (Jcp). The Tonnie-Paveloff weathering color transition is also commonly coincident with a similarly mappable break-in-slope (red arrow). Note that onset of the striped color character of part of the lower sandstone member (Jnss) here lies several tens of meters above the unit's base. The Snug Harbor Siltstone Member (Jns) weathers recessively in part, but comprises the mountain's summit here (orange arrow). Jcp is typically $>300 \mathrm{~m}$ thick in the study area for sense of scale

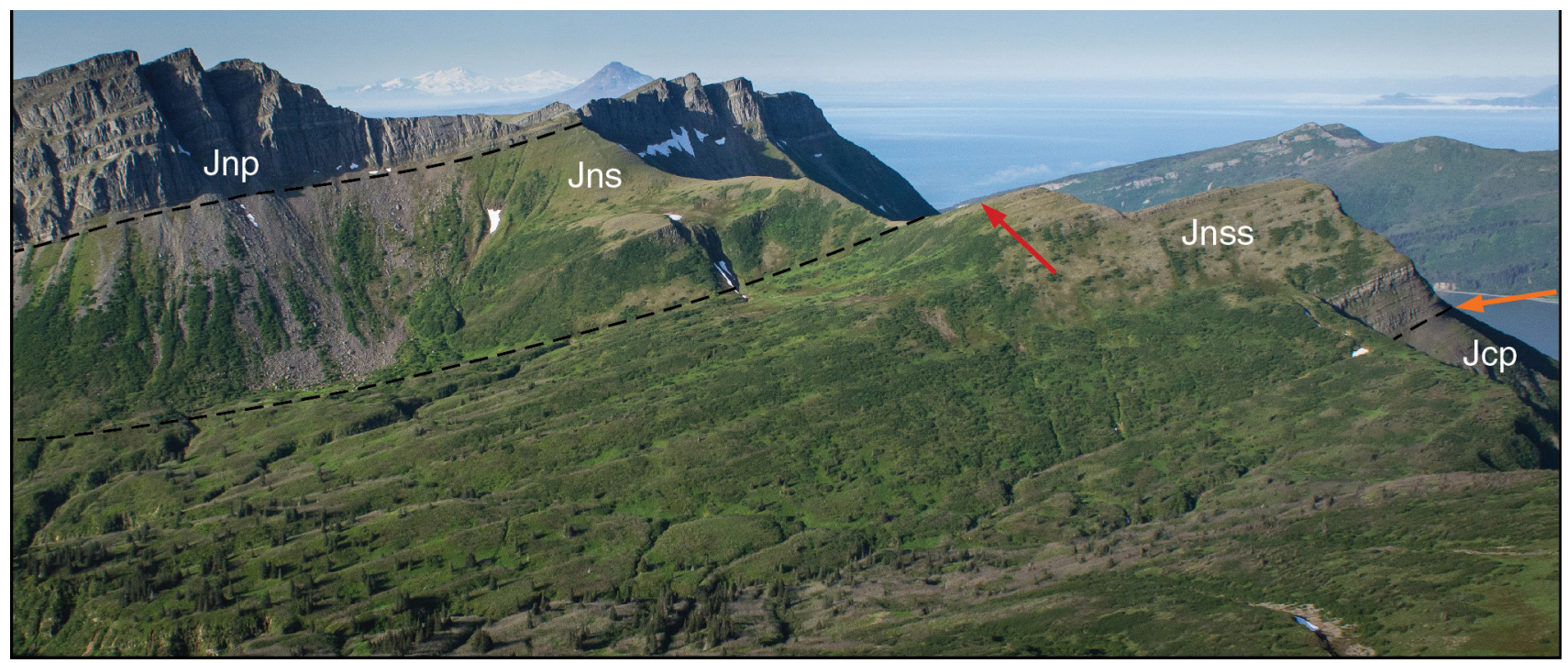

Figure 2-5. View southwestward of Cy Peak (immediately right of red arrow; fig. 2-1) and Shark Tooth Hill (photo-left skyline; figs. 2-1 and 2-3) area, exhibiting typical weathering profiles of Paveloff (Jcp) through Pomeroy Arkose (Jnp) members. The base of the lower sandstone (Jnss) lies at the break-in-slope marked by the orange arrow. A characteristic dip slope at the top of the lower sandstone marks the abrupt contact with the Snug Harbor Siltstone Member (Jns; red arrow). Cliffs consisting of Pomeroy strata are at photo-center and photo-left skyline. Jns is approximately $285 \mathrm{~m}$ thick for sense of scale. 
The geologic mapping criteria briefly outlined here, and more thoroughly summarized by Herriott and Wartes (in press [2014]), will serve in part as a basis for pending interpretive reports regarding sedimentation in the Cook Inlet forearc basin during latest Middle to Late Jurassic time. This work will contribute to a better understanding of basin evolution and the hydrocarbon potential of Mesozoic strata in the Cook Inlet region.

\section{ACKNOWLEDGMENTS}

We thank Rebekah Tsigonis for field assistance and camp support; Rick Stanley (U.S. Geological Survey) and Ken Helmold (Alaska Division of Oil \& Gas) for constructive conversations in the field; Mike Fell (Pathfinder Aviation) for helicopter support; Merril and Marti (Bear Mountain Lodge) for their hospitality; Jack Barber (Alaska Air Taxi); Bald Mountain Air; and David LePain and Andrea Loveland for careful review of this report. The Iniskin Peninsula area mapping project was funded by a substantial contribution from the U.S. Geological Survey STATEMAP Program (award no. G13AC00157).

\section{REFERENCES CITED}

Detterman, R.L. and Hartsock, J.K., 1966, Geology of the Iniskin-Tuxedni region, Alaska: U.S. Geological Survey Professional Paper 512, 78 p., 6 sheets, scale 1:63,360, http://www.dggs.alaska.gov/pubs/id/3873.

Herriott, T.M., and Wartes, M.A., in press [2014], Overview of geologic mapping-based observations of the Middle Jurassic Chinitna Formation and Upper Jurassic Naknek Formation in the Tilted Hills, Iniskin Peninsula, Cook Inlet, Alaska: Alaska Division of Geological \& Geophysical Surveys Preliminary Interpretive Report 2014-XX.

LePain, D.L., Stanley, R.G., and Helmold, K.P., 2013, Geologic framework and petroleum systems of Cook Inlet basin, south-central Alaska, in Stone, D.M., and Hite, D.M., eds., Oil and Gas Fields of the Cook Inlet Basin: American Association of Petroleum Geologists Memoir 104, p. 37-116.

Wartes, M.A., Herriott, T.M., Helmold, K.P., and Gillis, R.J., 2013, Preliminary stratigraphic interpretation of the Naknek Formation: Evidence for Late Jurassic activity on the Bruin Bay fault, Iniskin Peninsula, lower Cook Inlet, in Gillis, R.J., Overview of 2012 field studies: Upper Alaska Peninsula and west side of lower Cook Inlet, Alaska: Alaska Division of Geological \& Geophysical Surveys Preliminary Interpretive Report 2013-1H, p. 39-46, http://www.dggs.alaska.gov/ webpubs/dggs/pir/text/pir2013_001h.pdf. 



\title{
CHAPTER 3
}

\section{PRELIMINARY OBSERVATIONS: A FACIES ARCHITECTURE STUDY OF THE LOWER JURASSIC TALKEETNA FORMATION, INISKIN PENINSULA, ALASKA}

\author{
Katharine F. Bull ${ }^{1}$
}

Rocks of the Lower Jurassic Talkeetna Formation (Martin, 1926) define a $\geq 1,000$-km-long, northeast-trending belt of volcanic facies within the accreted intraoceanic Talkeetna Arc that stretch from the Chugach Mountains north of Anchorage to the Alaska Peninsula (fig. 3-1). Detterman and Hartsock (1966) divided the Talkeetna Formation into three conformable, continuous stratigraphic members, the Marsh Creek, Portage Creek, and Horn Mountain Tuff. For this study, a facies analysis approach was taken to describe the Talkeetna Formation in the map area in an attempt to better reflect the complexity of volcanic stratigraphy. Volcanic successions tend to be spatially controlled by volcanic vents and rarely contain continuous mappable units.

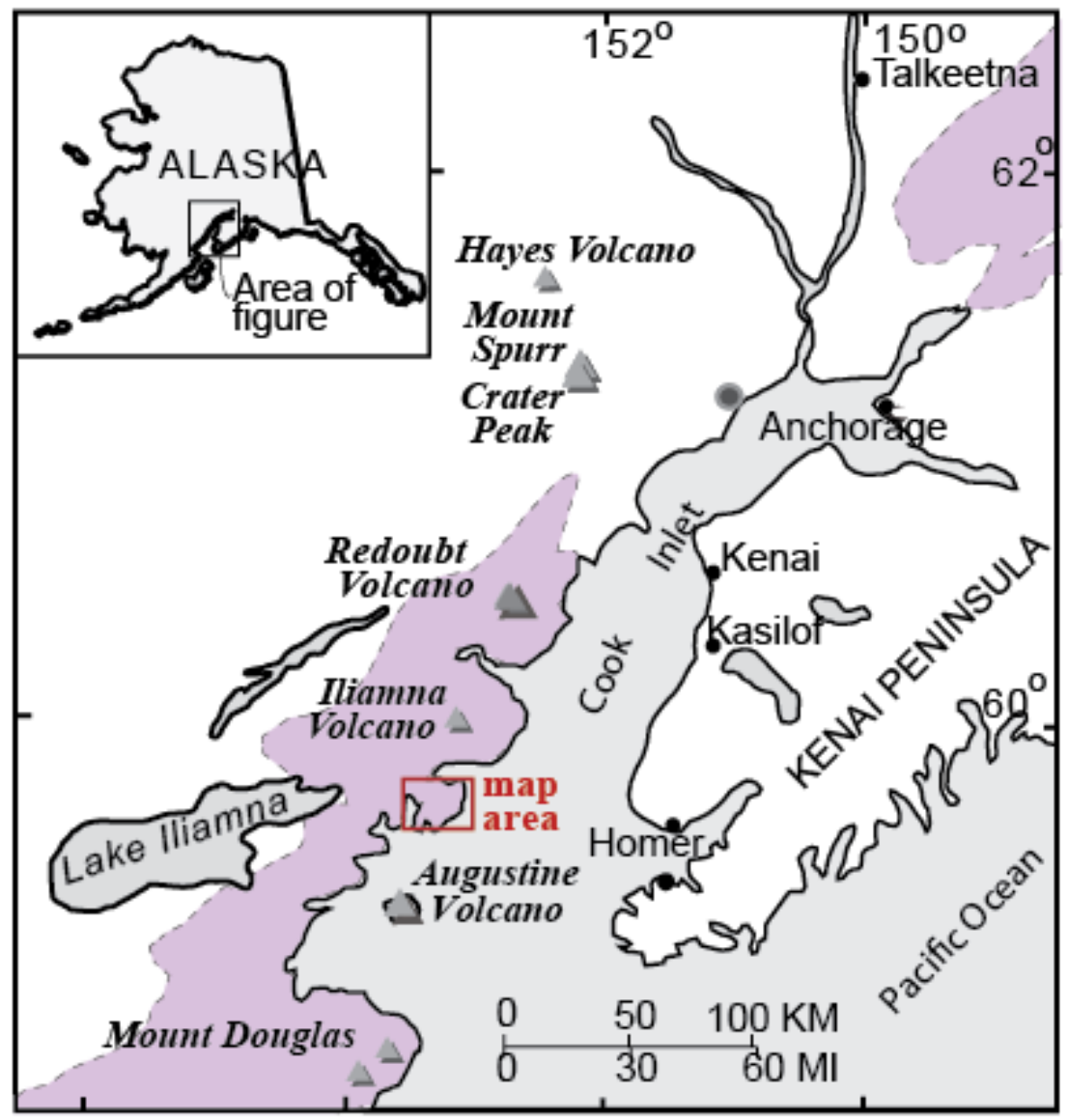

Figure 3-1. Location of Iniskin Peninsula map area (red square), and approximate location of the Talkeetna Arc (in purple) west and northwest of Cook Inlet (modified after Rioux and others, 2010).

Facies of the Talkeetna Formation in the Iniskin Peninsula map area are summarized in table 1. The Marsh Creek and Portage Creek members each consist of predominantly erosionally resistant, mafic to intermediate coherent facies (lavas and subvolcanic sills) that are tens to hundreds of meters thick, and associated monomictic volcaniclastic breccia facies (autoclastic breccias) (fig. 3-2). Possible pillows and fluidal-clast breccias are present locally associated with mafic lavas. The monomictic breccias include hyaloclastites (quench-fragmented autobreccias). Also volumetrically significant in the Marsh and Portage Creek member are non-stratified polymictic volcaniclastic breccia facies. Minor facies include thinly bedded volcaniclastic sandstone to pebble breccia-conglomerate facies (figs. 3-3A-C). No evidence of pyroclastic material was observed. 


\section{TABLE 1.}

Marsh-Portage Creek Member

I. Coherent facies association

A. Coherent facies

1. Lavas and subvolcanic sills

2. Dikes and intrusions

B. Monomictic breccia facies

C. Fluidal-clast breccia facies

II. Non-stratified polymictic volcaniclastic breccia facies

III. Thinly bedded volcaniclastic sandstone to pebble breccia-conglomerate facies

\section{Horn Mountain Member}

I. Coherent facies association

A. Coherent facies

1. Lavas and subvolcanic sills

2. Dikes and intrusions

B. Monomictic breccia facies

II. Stratified polymictic volcaniclastic breccia-conglomerate facies

III. Thinly bedded volcaniclastic sandstone to pebble breccia-conglomerate facies
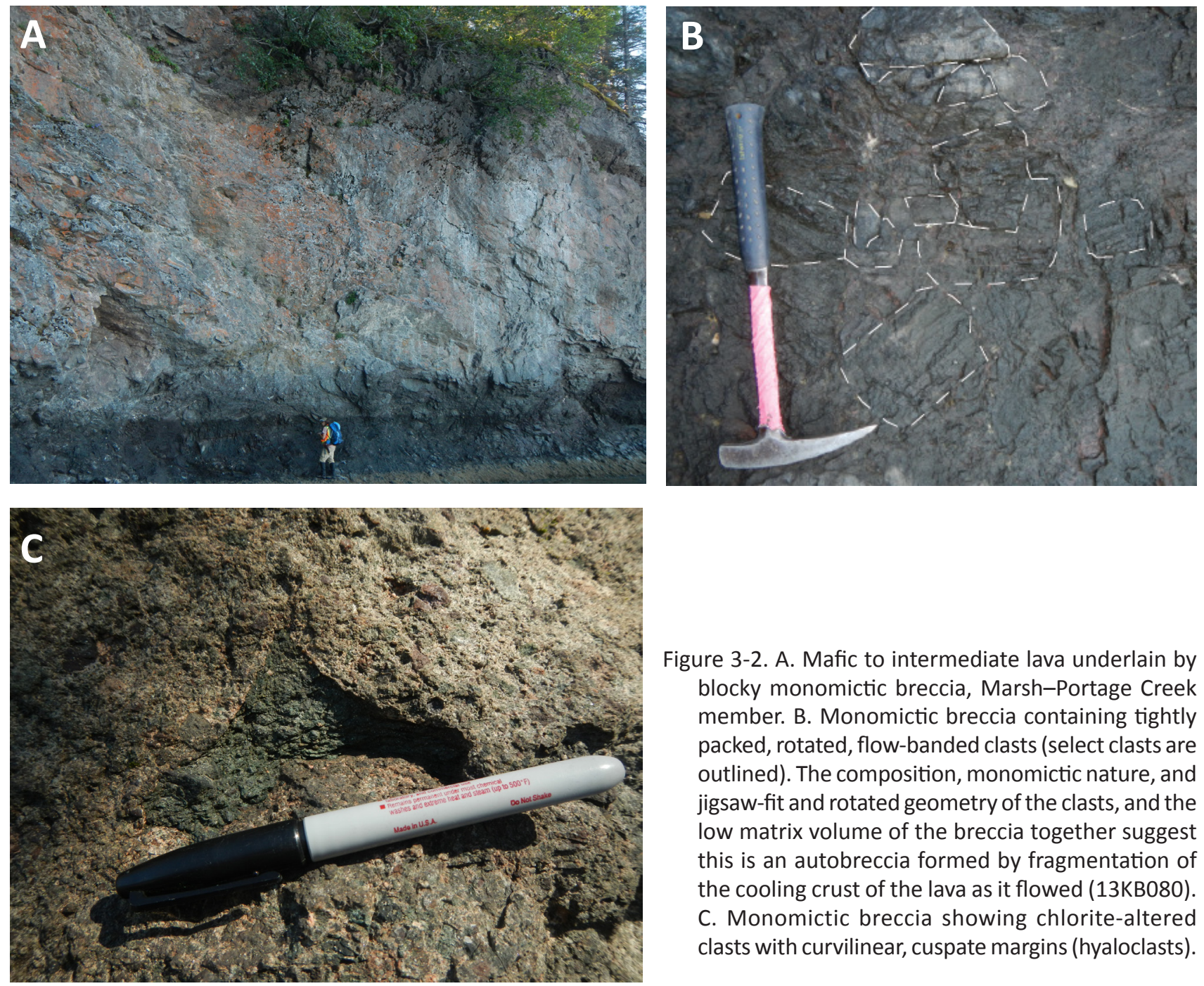

Figure 3-2. A. Mafic to intermediate lava underlain by blocky monomictic breccia, Marsh-Portage Creek member. B. Monomictic breccia containing tightly packed, rotated, flow-banded clasts (select clasts are outlined). The composition, monomictic nature, and jigsaw-fit and rotated geometry of the clasts, and the low matrix volume of the breccia together suggest this is an autobreccia formed by fragmentation of the cooling crust of the lava as it flowed (13KB080). C. Monomictic breccia showing chlorite-altered clasts with curvilinear, cuspate margins (hyaloclasts). 
The Horn Mountain member consists mainly of stratified polymictic volcaniclastic breccia-conglomerate facies, with minor mafic-intermediate lavas and sills. Thinly bedded volcaniclastic sandstone to pebble breccia-conglomerate facies also are present in the Horn Mountain member (fig. 3-3D). The composition in terms of clasts and matrix of the stratified facies is similar to non-stratified facies in the Marsh and Portage Creek members. The majority of the Horn Mountain facies are nonresistant and well weathered.

The Marsh Creek and Portage Creek members are indistinguishable in terms of lithofacies, and therefore the two members are combined combined into one member, the Marsh-Portage Creek member. However, facies of the Horn Mountain member are consistently separate and distinct, so the nomenclature of the Horn Mountain member is upheld.

Within the Marsh-Portage Creek member, the predominance of coherent lavas, the substantial volume of in situ and resedimented autoclastic breccias present, and the apparent paucity of pyroclastic material indicate that either the eruptive environment was primarily effusive, or syn-eruptive deposits of pyroclastic material were not well preserved. The thickest lava flows are hundreds of feet thick and underlie the highest peaks in the map area, suggesting that the peaks may be remnants of effusive eruptive centers.

In contrast, the Horn Mountain member contains the majority of weakly to well-bedded volcaniclastic deposits. Coherent facies that are present in the area tend to be thin and relatively small in volume; this area is therefore interpreted to represent deposition distal to the eruptive center(s).

Numerous observations are consistent with a marine environment of deposition for the Talkeetna Formation in the map area: the presence of hyaloclastite breccias that record quench fragmentation at the lava-water interface during effusion; structureless volcaniclastic breccias that suggest rapid or en masse deposition from sediment-water slurry flows and are consistent with subaqueous volcanic activity on the flanks of one or more growing effusive edifice(s); and thinly bedded volcaniclastic siltstone and sandstone facies, suggestive of deposition from sediment gravity flows and probable deposition of fine volcaniclastic material from suspension.

All Talkeetna Formation rocks have been altered to varying degrees. Based on field observations, alteration assemblages in the Marsh-Portage Creek member include local and patchy chlorite \pm sericite \pm albite, likely resulting from diagenesis, and less common zeolite and/or clay assemblages. Rocks of the Horn Mountain member in the map area, however, are noticeably softer and less resistant, suggesting they have been altered to zeolites and/or clay assemblages.

In summary, the Talkeetna Formation in the Iniskin Peninsula map area forms a belt of submarine volcanic facies dominated by lavas, sills, and related in-situ and resedimented autoclastic breccias. Polymictic volcaniclastic slope deposits and volcaniclastic turbidites are subordinate in volume. Resistant facies are dominated by proximal deposits that make up the Marsh-Portage Creek member. Less resistant, more distal, and well-bedded debris flows predominate in the Horn Mountain member.

A more detailed interpretation of facies, facies architecture, and post-depositional alteration and deformation of the Lower Jurassic Talkeetna Formation volcanic succession will be presented in a future publication.

\section{ACKNOWLEDGMENTS}

We thank Rebekah Tsigonis for field assistance and camp support; Rick Stanley (U.S. Geological Survey) and Ken Helmold (Alaska Division of Oil \& Gas) for constructive conversations in the field; Mike Fell (Pathfinder Aviation) for helicopter support; Merril and Marti (Bear Mountain Lodge) for their hospitality; Jack Barber (Alaska Air Taxi); Bald Mountain Air; and David LePain for careful review of this report. The Iniskin Peninsula area mapping project was funded by a substantial contribution from the U.S. Geological Survey STATEMAP Program (award no. G13AC00157).

\section{REFERENCES}

Detterman, R.L., and Hartsock, J.K., 1966, Geology of the Iniskin-Tuxedni region, Alaska: U.S. Geological Survey Professional Paper 512, 78 p., 6 sheets, scale 1:63,360, http://www.dggs.alaska.gov/pubs/id/3873.

Martin, G.C., 1926, The Mesozoic stratigraphy of Alaska: U.S. Geological Survey Bulletin 776, 493 p., 4 sheets.

Rioux, M., Mattinson, J., Hacker, B., Kelemen, P., Blusztajn, J., Hanghoj, K., and Gehrels, G., 2010, Intermediate to felsic middle crust in the accreted Talkeetna arc, the Alaska Peninsula and Kodiak Island, Alaska-An analogue for lowvelocity middle crust in modern arcs: Tectonics, v. 29, 17 p. 

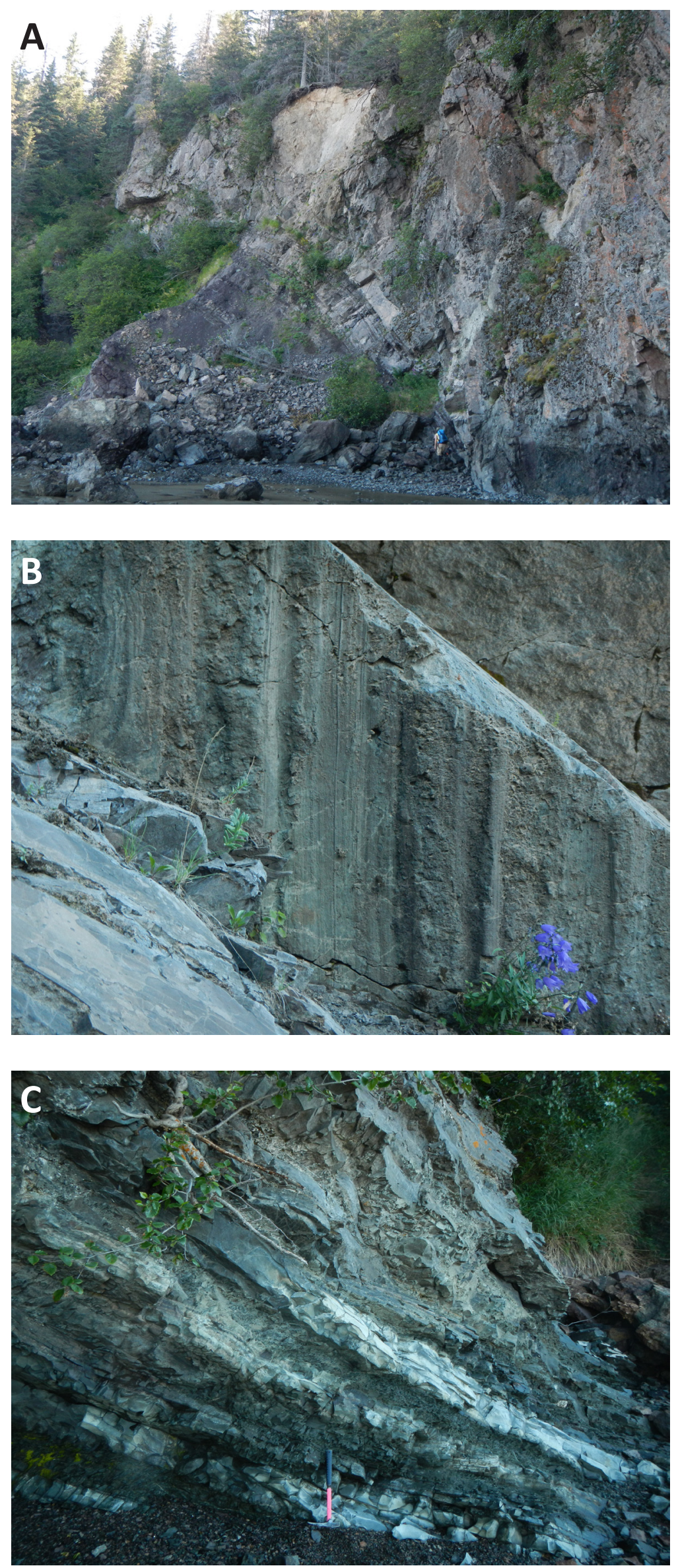

Figure 3-3. Thinly bedded volcaniclastic siltstones and very-fine- to fine-grained sandstones in the Marsh-Portage Creek member in two coastal outcrops (13KB080). A. Volcaniclastic siltstones, graded sandstones, and granule breccia-conglomerates with occasional outsized cobbles are intercalated between an amygdaloidal basalt(?) autobreccia at the base and autobreccia and basalt seen in figure 3-2, conformably overlying the sediments. B. Looking up at tool markings at the base of a mediumgrained volcaniclastic sandstone within outcrop in A. C. Thinly bedded volcaniclastic siltstones and fine- to medium-grained sandstones $100 \mathrm{~m}$ north of outcrop in A. D. Thinly bedded volcaniclastic siltstone, sandstone, and pebble breccia-conglomerate crop out within the Horn Mountain member (13KB105).

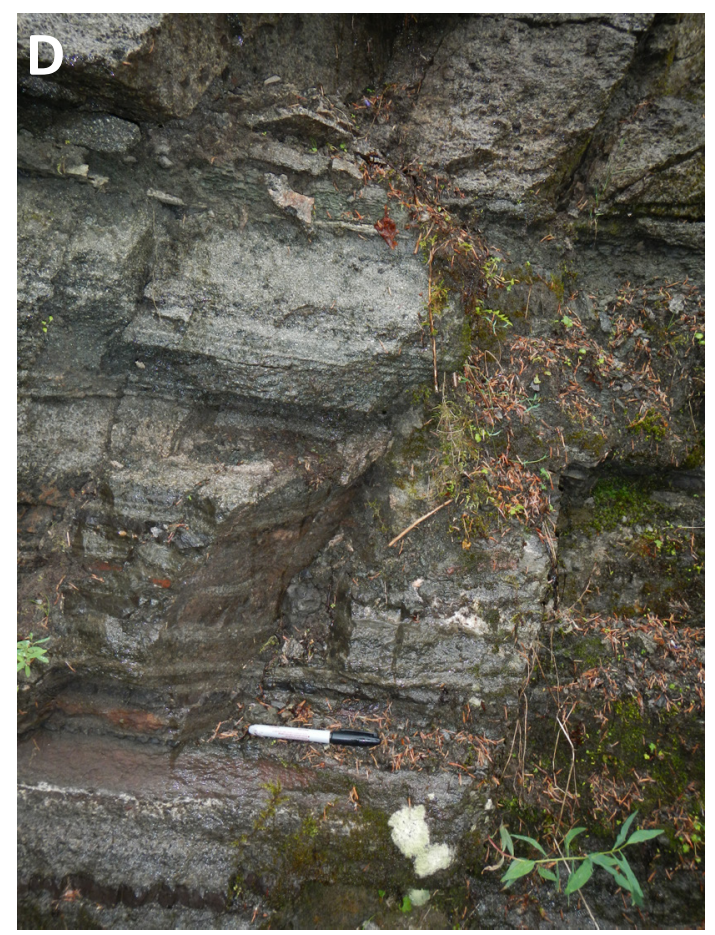




\section{CHAPTER 4}

\section{PRELIMINARY KINEMATIC EVIDENCE FOR RIGHT-LATERAL SLIP ALONG A SYSTEM OF STEEPLY-DIPPING FAULTS IN THE HANGING WALL OF THE BRUIN BAY FAULT, INISKIN PENINSULA, LOWER COOK INLET, ALASKA}

Paul M. Betka ${ }^{1}$ and Robert J. Gillis ${ }^{1}$

\section{INTRODUCTION}

An ongoing program by the Alaska Division of Geological \& Geophysical Surveys aims to understand the Mesozoic and Cenozoic geologic evolution of the northwestern margin of the Cook Inlet forearc basin. As part of that program, this study is directed at understanding the kinematic evolution, relative timing, and tectonic significance of a system of steeply dipping faults that occur in the hanging wall of the Bruin Bay fault, near the Iniskin Peninsula, Cook Inlet, Alaska (fig. 4-1).

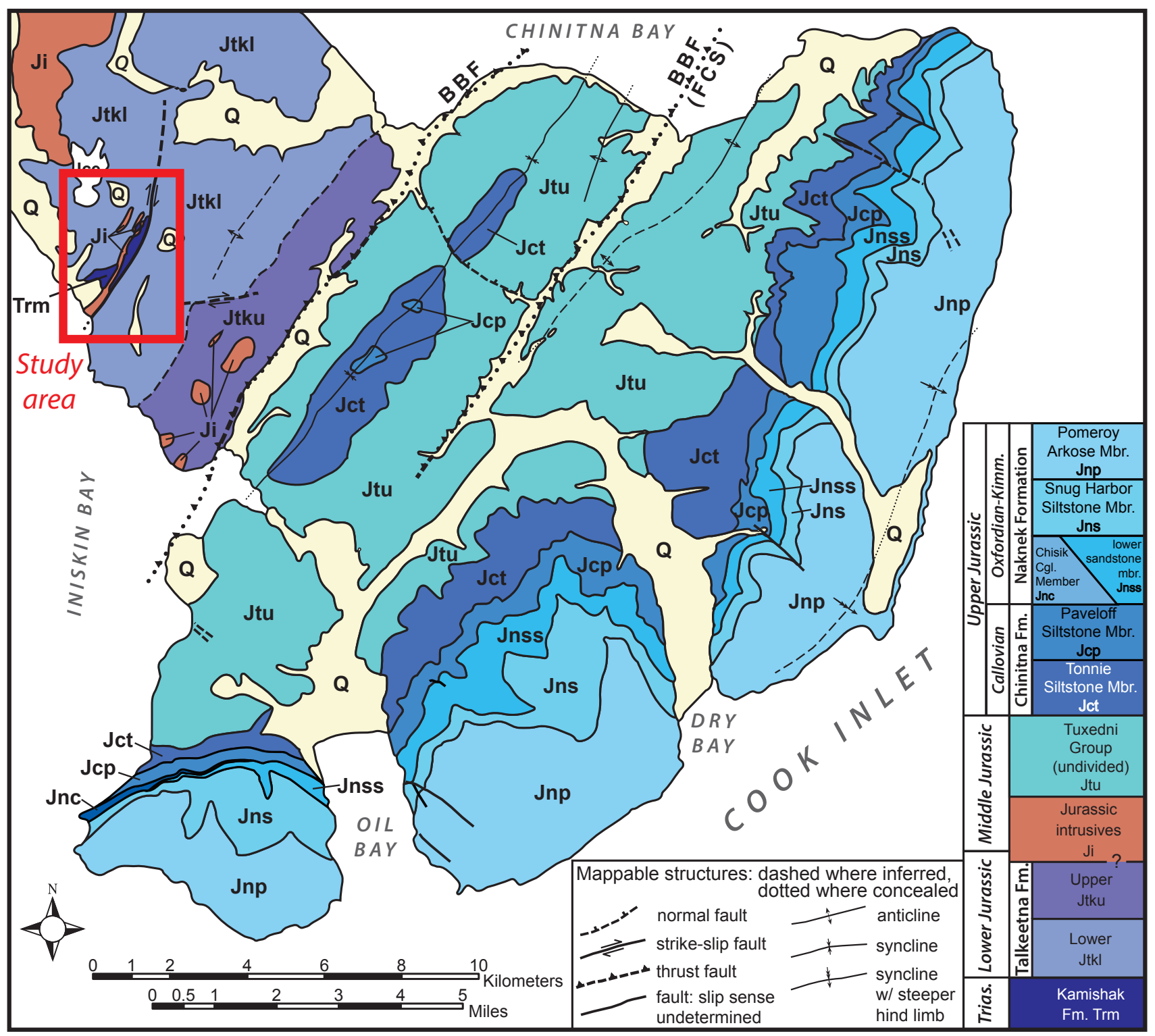

Figure 4-1. Simplified preliminary inch-to-mile geologic map of the Iniskin Peninsula constructed from data collected during the 2013 DGGS mapping campaign. The study area and fault zone discussed are shown within the red box.

${ }^{1}$ Alaska Division of Geological \& Geophysical Surveys, 3354 College Rd., Fairbanks, Alaska 99709-3707; paul.betka@alaska.gov; robert.gillis@alaska.gov 
The Bruin Bay fault strikes northeastward more than $450 \mathrm{~km}$ from the upper Alaska Peninsula to near the northwest terminus of Cook Inlet. In lower Cook Inlet, it defines the tectonic boundary between Mesozoic and Cenozoic sediments of the Cook Inlet forearc basin to the southeast and the crystalline batholith and volcanic edifice of the Jurassic Talkeetna arc toward the northwest. Hanging wall and footwall exposures indicate a significant component of top-southeast reverse motion along a northwest-dipping (40-50 where measured) fault plane. Detterman and Hartsock (1966) first mapped a system of steeplydipping northeast-striking faults that are present in the hanging wall of the Bruin Bay fault and locally define the contacts between Jurassic volcanic and volcaniclastic deposits of the Talkeetna Formation and Triassic (age uncertain) marbles and metasedimentary rocks of the Kamishak Formation. Detterman and Reed (1980) postulate that the steeply-dipping faults are part of the Bruin Bay fault system and they suggest a genetic relationship among all of the faults in the hanging wall with the Bruin Bay fault. Both Detterman and Hartsock (1966) and Detterman and Reed (1980) interpret the system to be left slip, perhaps accommodating 19-65 km of sinistral displacement on the basis of poorly understood, non-unique stratigraphic piercing points. However, the sense of slip and relative timing gleaned from map patterns of the hanging-wall faults is unclear and their tectonic significance remains ambiguous.

In this paper, we present field observations and preliminary results from an ongoing kinematic analysis of a well-exposed northeast-striking fault strand in the hanging wall of the Bruin Bay fault where it crops out for $\sim 3.2 \mathrm{~km}$ between the head of Iniskin Bay and the headwaters of Roscoe Creek (fig. 4-1). Here, the fault dips steeply northwest and defines the southeastern contact between Jurassic volcanic and volcaniclastic rocks of the Talkeetna Formation in the footwall and rock units including Triassic(?) marble, Jurassic(?) hypabyssal felsic intrusive rocks, and the Talkeetna Formation in the hanging wall. This ongoing study is designed to test whether the Bruin Bay fault is genetically related to the steeply dipping faults in its hanging wall or if each set of faults reflects a separate phase of deformation. Initial fieldwork for this project was completed during July and early August 2013.

\section{FIELD OBSERVATIONS}

In the study area (figs. 4-1, 4-2), the northwestern contact between Triassic(?) marble and the Talkeetna Formation is well exposed and moderately deformed. It is tentatively interpreted to reflect a non-conformable contact. The contact is intruded by a felsic dike that is mostly parallel to the contact, but locally cross-cuts it (fig. 4-2). Both the dike and the contact are cut by several minor strike-slip fault planes. Across-strike toward the southeast, the Triassic marble contains a well-defined gneissic banding that is upright and probably reflects recrystallization of original compositional layering (bedding?). The areal width of the marble is $\sim 320 \mathrm{~m}$ (fig. 4-3A). Brittle deformation in the marble intensifies toward the southeast, where a decameters-wide fault zone that contains cataclasite defines the southeastern contact between the marble and Talkeetna Formation. The contact dips steeply toward the northwest and is subparallel to gneissic banding in the marble (fig. 4-3A). Along-strike of the fault toward the northeast from the location of figure 4-3A, the fault truncates the northwestern contact

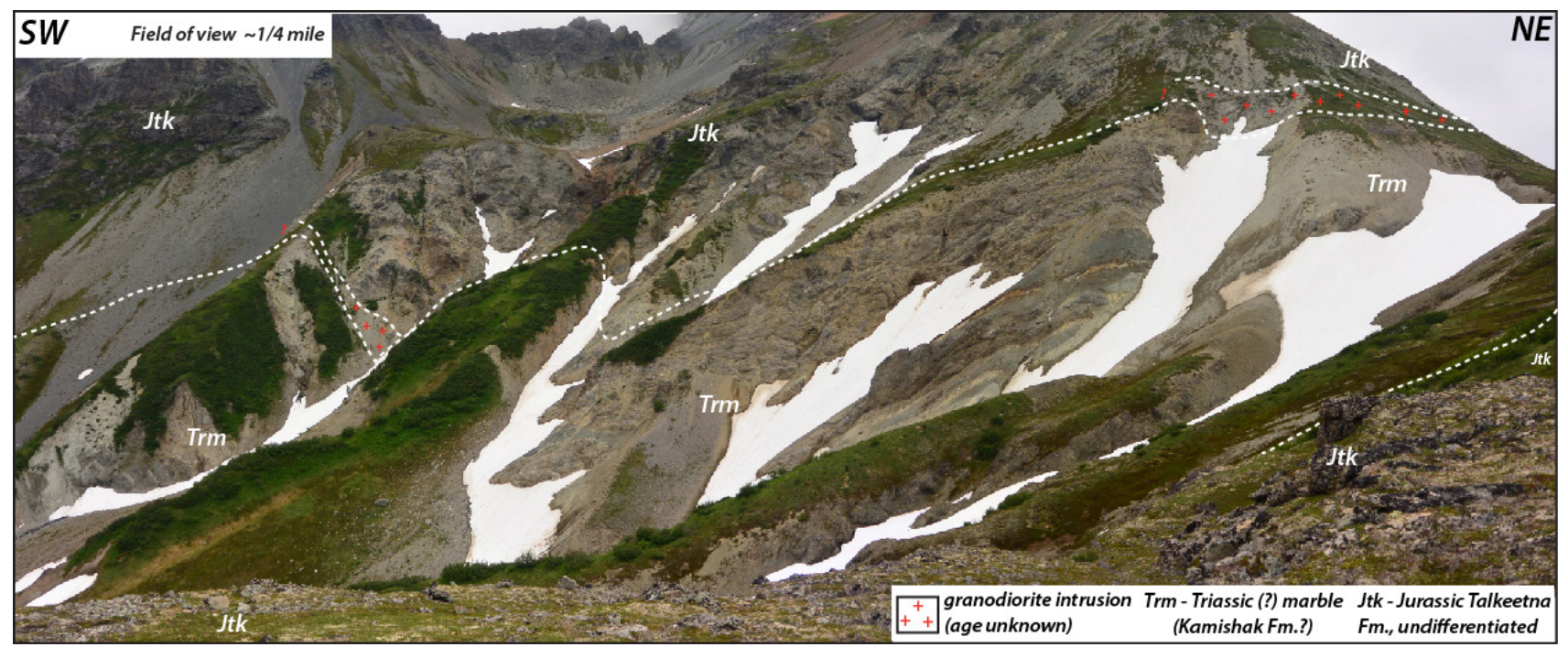

Figure 4-2. Panoramic view looking northwest showing the outcrop extent of Triassic(?) marble (Trm) in the map area. Along the northwestern boundary, the marble is in contact with Jurassic volcanic breccias of the Talkeetna Formation (Jtk). The contact is weakly deformed and intruded by a medium-grained granodiorite dike (red "+" symbols). The eastern contact (out of field of view at base of photo) is defined by a northeast- to north-northeast-striking fault zone (see fig. 4-3). Viewpoint for this photograph is shown in figure 4-3. 

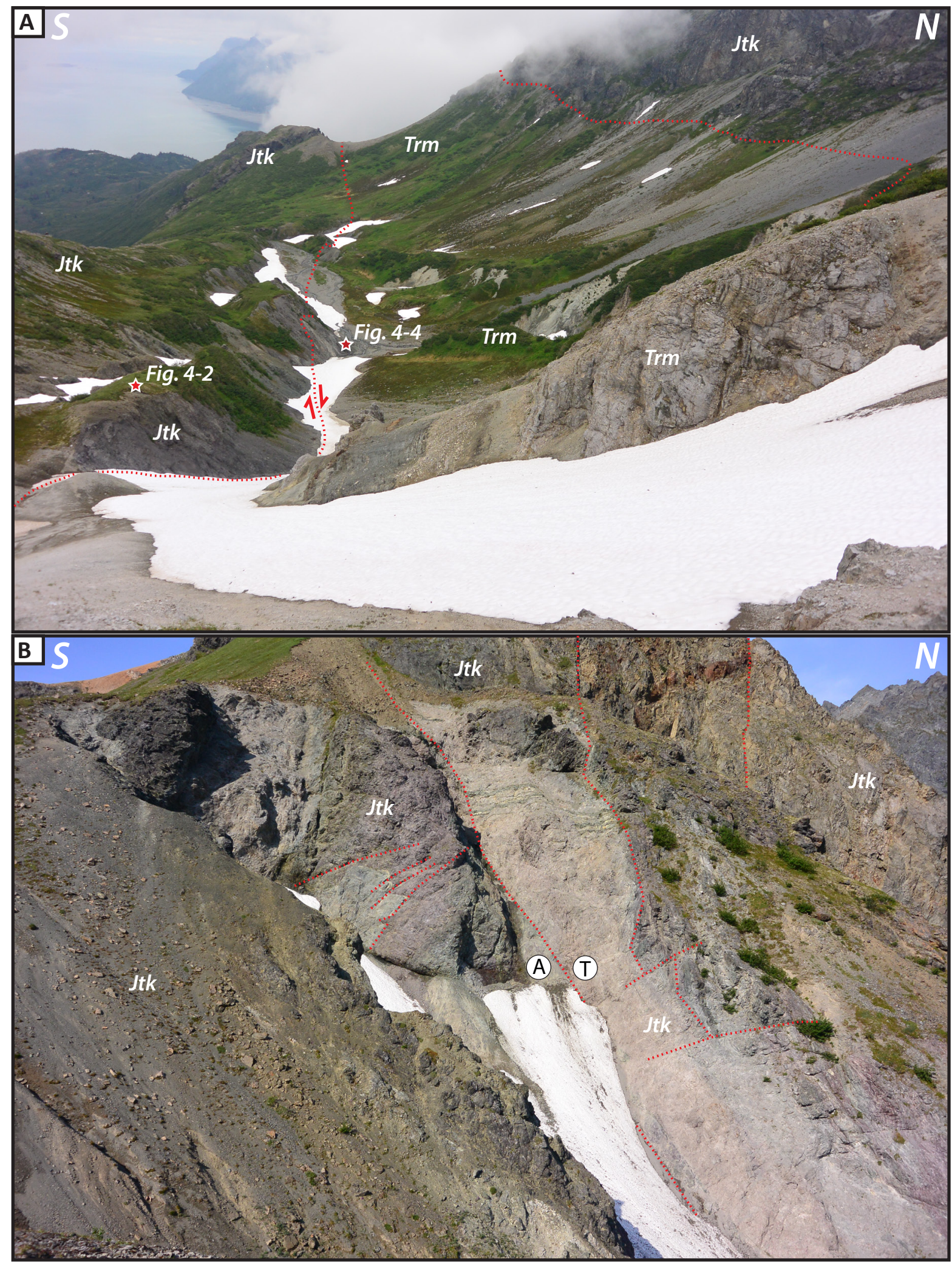

Figure 4-3. A. View looking west-southwest showing map trace of the southwestern contact of the Triassic marble (Trm) with the Talkeetna Formation (Jtk); outcrop width of the Triassic marble is $\sim 320 \mathrm{~m}$. The southwestern contact is tectonized and defined by a decameter wide right-lateral strike-slip fault zone. Compositional layering in the marble (foreground) defines a gneissic banding that is upright and interpreted to reflect original bedding. Locations of figures 4-2 and 4-4 are marked with red stars. B. Trace of fault zone in A where it cuts across a gully above the headwaters of Roscoe Creek. Several fault planes are highlighted by red dashed lines and define a decameters-wide fault zone. Sense of slip on fault is inferred based on kinematic data collected elsewhere along the fault trace (for example, figs. 4-4, 4-5). T, toward; A, away. 
between the marble and Talkeetna Formation, thus cutting out the marble and juxtaposing Talkeetna Formation along both sides of the fault. This relationship is best confirmed where the fault is exposed in a steeply sloped gulley above the headwaters of Roscoe Creek (fig. 4-3B). Here, the marble is absent and the Talkeetna Formation is present on either side of a fault plane that dips steeply toward the northwest. A decameters-wide damage zone is defined by several subsidiary faults (fig. 4-3B). Unfortunately, this outcrop is inaccessible due to steep terrain and loose rock, ruling out measurements from this segment of the fault.

\section{FAULT KINEMATIC METHODS}

To determine the overall sense of slip along the fault, we collected a fault-slip dataset from numerous discrete fault surfaces that occur in the fault zone that defines the southeastern contact between the Talkeetna and Kamishak Formations. A population of fault-slip data was collected by measuring the attitudes of fault surfaces and associated slip lineations. The sense of shear on individual faults was determined using kinematic indicators including Riedel shears, steps on fault surfaces, preferred orientations of associated tensile or sigmoidal veins, and other common methods (for example, Petit, 1987). Shear-sense indicators were weighted by quality. To interpret the population of fault-slip data and test for multiple overprinting deformations along the fault zone, we followed the graphical methods of Marrett and Allmendinger (1990). Measurements were collected along the fault where it crops out in a low saddle between the headwaters of Roscoe Creek and Iniskin Bay (fig. 4-3A). Here the fault zone is defined by a cataclasite in the Triassic marble that has a minimum thickness of $2 \mathrm{~m}$ (fig. 4-4A). Discrete slip surfaces in the cataclasite are abundant and commonly contain well-preserved slip lineations (for example, fig. 4-4B).

\section{FAULT KINEMATIC RESULTS}

Preliminary results from 17 discrete fault planes are presented in figure 4-5. All of the 17 faults analyzed strike northeast and contain moderately to shallowly plunging slip lineations $\left(<40^{\circ}\right.$ plunge). The sense of shear is dominantly right-lateral with a subordinate dip-slip component (fig. 4-5A). Shortening and extension axes, which were calculated for each fault plane, form well-defined clusters. Shortening axes plunge shallowly west and east, and extension axes plunge shallowly north and south (fig. 4-5B). Principal kinematic axes (directional maxima for shortening and extension axes) were calculated by the linked-Bingham method and used to construct a fault-plane solution that reflects an average fault-plane orientation and sense of slip from the population of faults. Results indicate an average sense of slip along the fault zone that is dominantly dextral strike-slip along a subvertical, northeast-striking surface (fig. 4-5B). Clustering of extension and shortening axes from the population of faults suggests that all of the faults formed during the same deformation, and thus do not reflect multiple overprinting slip events.

\section{SUMMARY}

Preliminary kinematic results from this study indicate that at least one of the steeply dipping faults in the hanging wall of the Bruin Bay fault formed in a tectonic setting favorable to right-lateral strike-slip motion along steeply dipping surfaces, and that locally the juxtaposition of Triassic(?) marble against the Jurassic Talkeetna Formation occurred along a strikeslip fault. These results suggest that deformation along steeply dipping northeast-striking faults in the hanging wall of the Bruin Bay fault may be kinematically distinct from the Bruin Bay fault, which itself is thought to reflect mostly reverseslip motion, possibly implying different tectonic origins for either fault. We postulate that brittle deformation associated with the Bruin Bay fault system could reflect a multiphase kinematic history that ultimately resulted in heterogeneous fault kinematics in the study area. Ongoing work during 2014 will include collecting similar kinematic datasets from Bruin Bay fault as well as other faults in the region.

\section{ACKNOWLEDGMENTS}

We thank Rebekah Tsigonis for field assistance and camp support; Rick Stanley (U.S. Geological Survey) and Ken Helmold (Alaska Division of Oil \& Gas) for constructive conversations in the field; Mike Fell (Pathfinder Aviation) for helicopter support; Merril and Marti (Bear Mountain Lodge) for their hospitality; Jack Barber (Alaska Air Taxi); Bald Mountain Air; and David LePain for careful review of this report. The Iniskin Peninsula area mapping project was funded by a substantial contribution from the U.S. Geological Survey STATEMAP Program (award no. G13AC00157). 

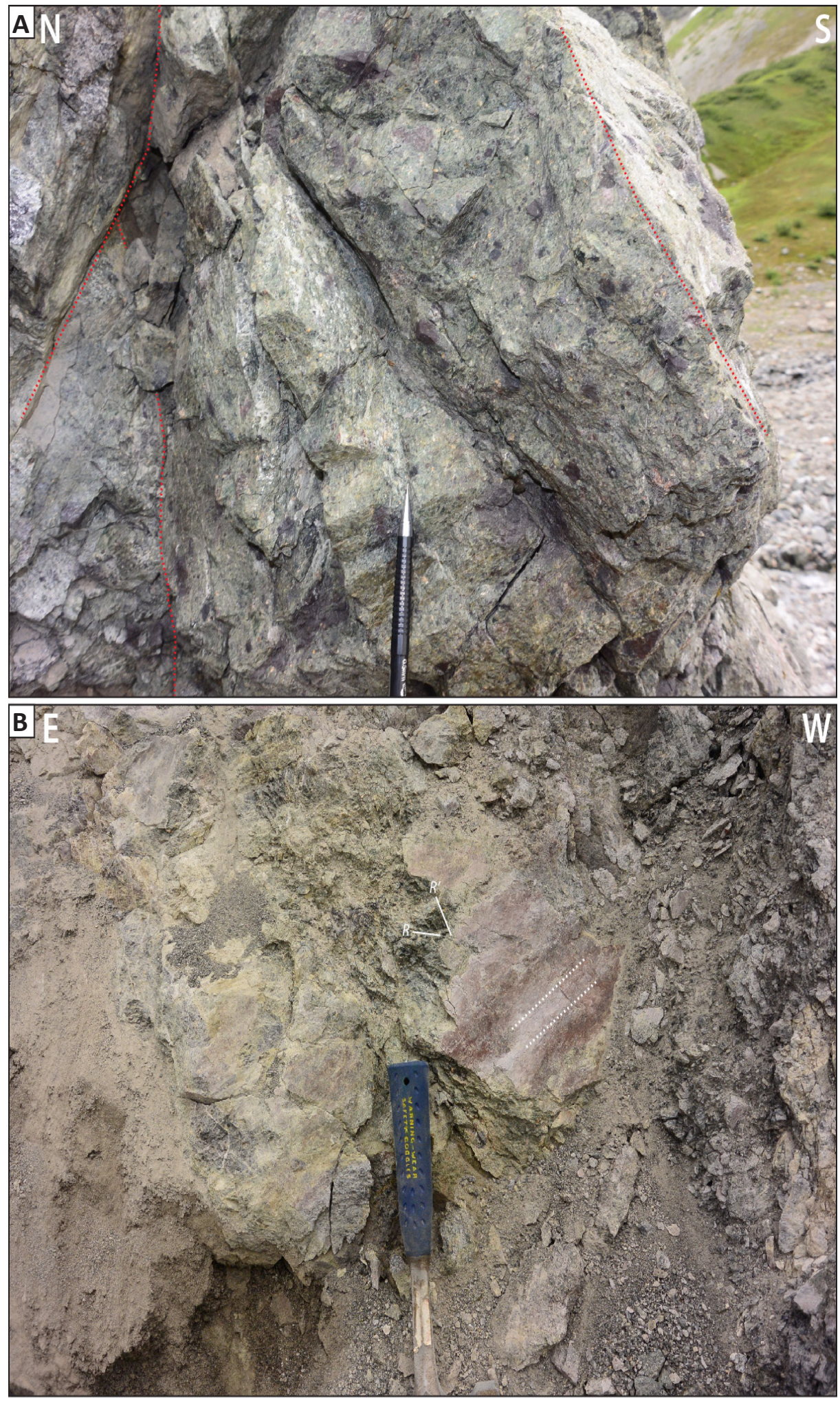

Figure 4-4. A. Fault-zone cataclasite contained within the Triassic marble. Several discrete fault planes that contain slip lineations are highlighted with dashed lines. Location is shown in figure 4-3A. B. A fault surface that contains slip lineations defined by calcite slicken fibers and fault-plane mullions. Slip lineations are highlighted by white dashed lines and plunge moderately $\left(\sim 35^{\circ}\right)$ toward the northeast. Sense of shear on this fault plane is interpreted to be right-lateral on the basis of Riedel shears that intersect the fault surface ( $R$ and $\left.R^{\prime}\right)$. 


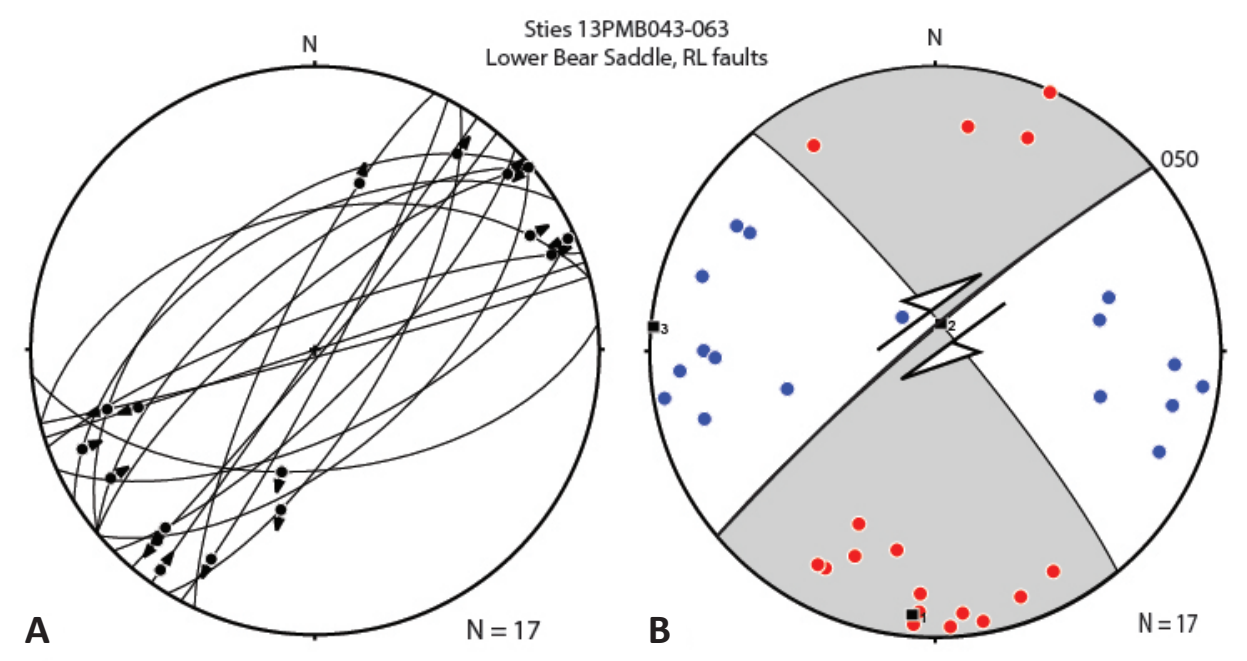

Figure 4-5. Synthesis of fault-slip data from 17 minor fault surfaces collected in the fault zone in the vicinity of figure 4-4. A. Equal-area stereographic projection showing fault-plane strike and dip (great circles), the trend and plunge of slip lineations associated with each fault (black dots), and sense of motion of the hanging wall (arrows on slip lineations). B. Equal-area stereographic projection showing distribution of shortening axes (blue dots) and extension axes (red dots) from each of the faults in A. Average directional maxima of shortening and extension axes (kinematic axes) are plotted (black squares) using the "linked-Bingham" method of the computer software package FaultKin (1-extension, 2-intermediate, and 3-shortening axis; Marrett and Allmendinger, 1990; Allmendinger et al., 2012). The fault-plane solution (nodal planes, gray and white dihedra) was constructed from the kinematic axes and is sympathetic with overall right-lateral shear within a subvertical northeast-striking $\left(050^{\circ}\right)$ strike-slip fault zone. $\mathrm{N}=$ number of faults in population. Kinematic analyses of fault slip data are after the methods of Marrett and Allmendinger (1990).

\section{REFERENCES}

Allmendinger, R.W., Cardozo, N.C., and Fisher, D., 2012, Structural geology algorithms-Vectors and tensors in structural geology: Cambridge, England, Cambridge University Press, 302 p.

Detterman, R.L., and Hartsock, J.K., 1966, Geology of the Iniskin-Tuxedni region, Alaska: U.S. Geological Survey Professional Paper 512, 78 p., 6 sheets, scale 1:63,360, http://www.dggs.alaska.gov/pubs/id/3873.

Detterman, R.L., and Reed, B.L., 1980, Stratigraphy, structure, and economic geology of the Iliamna Quadrangle, Alaska: U.S. Geological Survey Bulletin 1368-B, p. B1-B86, 1 sheet, scale 1:250,000, http://www.dggs.alaska.gov/pubs/id/3682.

Marrett, R.A., and Allmendinger, R.W., 1990, Kinematic analysis of fault-slip data: Journal of Structural Geology, v. 12, p. 973-986.

Petit, J.P., 1987, Criteria for the sense of movement on fault surfaces in brittle rocks: Journal of Structural Geology, v. 9 , no. 5/6, p. 597-608. 


\title{
CHAPTER 5
}

\section{A NEW OCCURRENCE OF OIL-STAINED ROCKS WITHIN A SMALL FAULT ZONE INVOLVING THE MIDDLE JURASSIC CYNTHIA FALLS FORMATION, TUXEDNI GROUP, NORTHERN INISKIN PENINSULA}

\author{
Marwan A. Wartes ${ }^{1}$ and Trystan M. Herriott ${ }^{1}$
}

\section{INTRODUCTION}

The Iniskin Peninsula of western Cook Inlet (fig. 5-1) has long been known as a prospective region for hydrocarbons due to surface oil and gas seeps, which were recognized by Russian observers in 1853 and are among the first documented seeps in Alaska (Martin, 1905). Geologic investigations that addressed the seeps and industry exploration continued intermittently for the first half of the twentieth century (Martin and Katz, 1912; Moffit, 1927; Detterman and Hartsock, 1966), but subsequent studies have been limited (for example, Blasko, 1976).

The most detailed geologic analysis of the Iniskin Peninsula is provided in the seminal U.S. Geological Survey Professional Paper 512, by Detterman and Hartsock (1966). Their mapping suggested that the seeps are likely controlled by faults or closely-spaced joints. Furthermore, their summary of the hydrocarbon shows from three exploration wells on the Iniskin Peninsula indicated that the presence of oil and gas was associated with steeply dipping joints and fault zones intersected by the wells. The lack of evidence for significant porosity in the unfaulted Jurassic strata also suggested that structures were serving as the main conduit for fluid migration.

Detterman and Hartsock (1966) projected their mapped faults into areas where oil was seeping through Quaternary cover. However, they did not document any oil-stained outcrops associated with a mapped structure. The purpose of this report is to briefly describe a newly discovered outcrop of oil-stained rocks on the Iniskin Peninsula that is preferentially charged within the damage zone of a small fault. We conclude by briefly discussing some of the larger questions surrounding the timing of hydrocarbon maturation, migration, and tectonic deformation that are key to better understanding the petroleum system in the region.

\section{NEW FAULT-RELATED OIL-STAINED LOCALITY2}

During the course of constructing a detailed geologic map of the Iniskin Peninsula (see project overview [chapter 1, this volume]), a locality exhibiting a moderate to strong petroliferous odor was discovered along Park Creek (fig. 5-1). Outcrops along the northwest bank of the creek are discontinuous and often partially covered; exposure quality at the oil-stained locality is enhanced by recent slumping of overlying colluvium and vegetation (fig. 5-2). Our mapping indicates the exposure is in the upper part of the Middle Jurassic Cynthia Falls Sandstone of the Tuxedni Group and lies in the southeast limb of the Fitz Creek anticline (figs. 5-1 and 5-3).

The oil-stained zone occupies the central part of the cutbank exposure and consists of dark greenish-gray, argillaceous sandstone (fig. 5-2). The interval is friable and exhibits evidence of shearing, including phacoid development and probable fault gouge. On either side of the fault, the exposed rock has no detectable hydrocarbon odor and consists of undeformed, light gray- and tan- to brown-weathering, well-indurated, fine-grained feldspathic graywacke. The sandstone also contains coalified wood fragments. The magnitude of offset and orientation of the fault zone are unclear, but the structure is subvertical and likely strikes approximately east-west.

Limited exposure hampers mapping of the oil-stained fault beyond the immediate outcrop. However, the inferred orientation is consistent with a number of other faults and fracture swarms on the peninsula that were described as 'cross faults' by Detterman and Hartsock (1966). Approximately 2 miles east of Park Creek, two subvertical faults cut across the Tilted Hills, offsetting the Chinitna and Naknek Formations (chapter 2, this volume). These faults are well exposed in the headwaters of Sinking and Covey creeks, yielding apparent north-side-up stratigraphic separations. Detterman and Hartsock (1966) mapped only the more northern fault along upper Sinking Creek (reproduced in fig. 5-1). The fault observed in upper Covey Creek (chapter 2, this volume) strikes approximately 110 degrees and may be the same fault noted at the oil-stained locality. Regardless, these faults are part of a family of structures oriented approximately perpendicular to the major fold axes on the Iniskin Peninsula (Detterman and Hartsock, 1966).

\footnotetext{
${ }^{1}$ Alaska Division of Geological \& Geophysical Surveys, 3354 College Rd., Fairbanks, Alaska 99709-3707; marwan.wartes@alaska.gov; trystan.herriott@alaska.gov

${ }^{2}$ Location coordinates: N59.81157 ${ }^{\circ}$ W153.10051 ${ }^{\circ}$ (NAD27AK)
} 


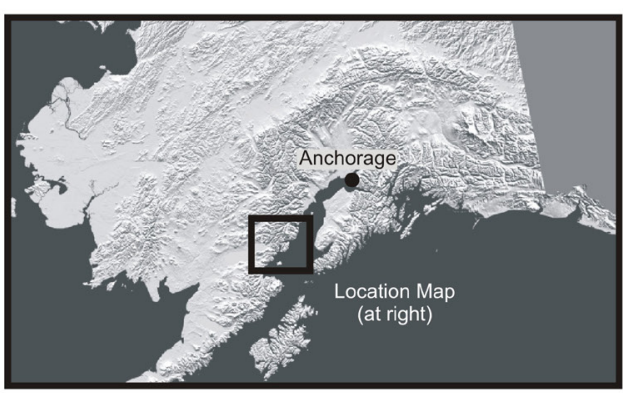

\begin{tabular}{|cll|}
\hline Naknek & Jnp & Pomeroy Arkose \\
Formation & Jns & Snug Harbor Siltstone \\
& Jnss & lower sandstone \\
\hline Chinitna & Jcp & Paveloff Siltstone \\
Formation & Jct & Tonnie Siltstone \\
\hline & Jtb & Bowser \\
& Jtt & Twist Creek Siltstone \\
Tuxedni & Jtc & Cynthia Falls Sandstone \\
Group & Jtf & Fitz Creek Siltstone \\
& Jtg & Gaikema Sandstone \\
& Jtr & Red Glacier \\
\hline
\end{tabular}
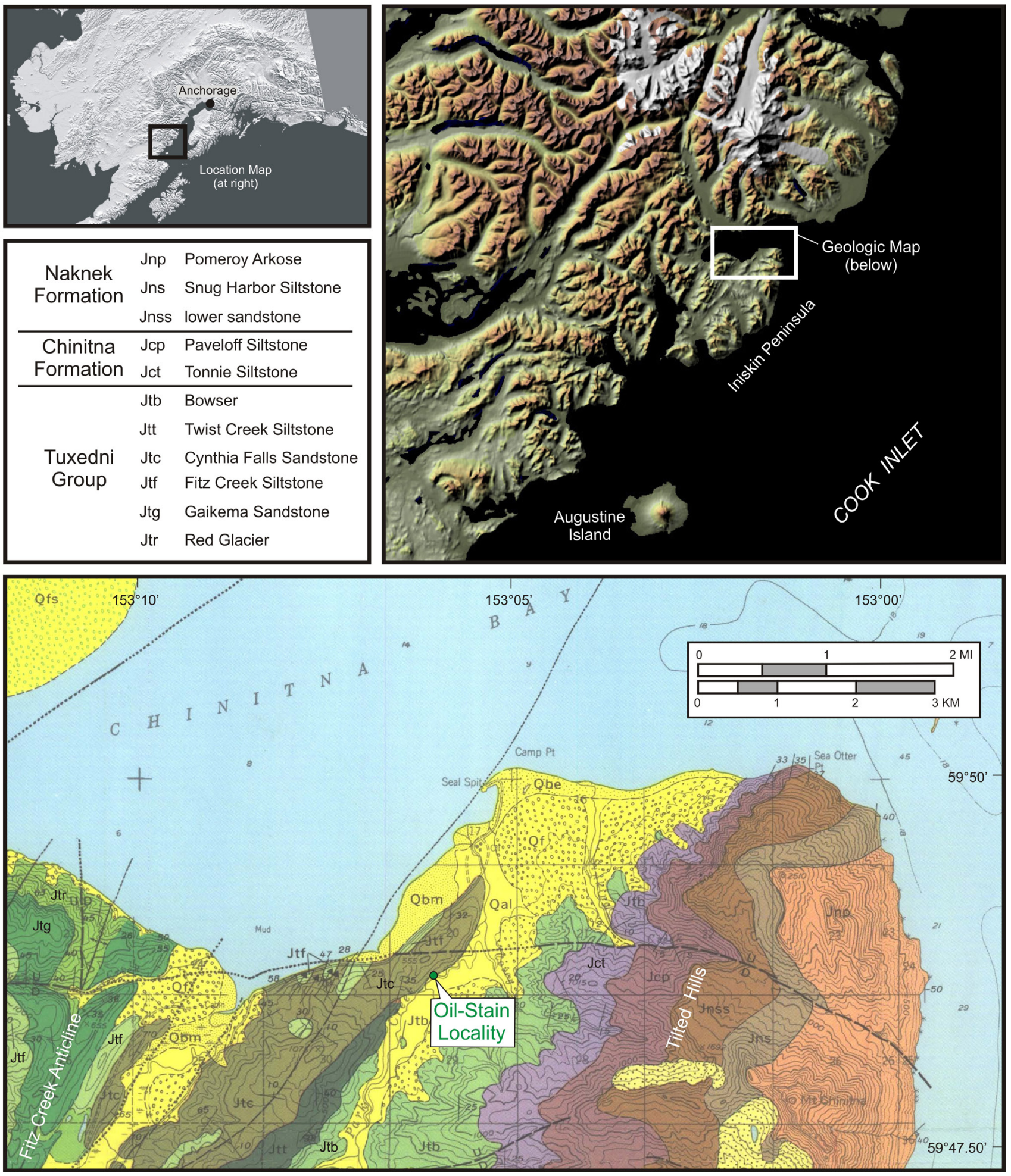

Figure 5-1. Location map of southern Alaska (upper left); shaded-relief map of western Cook Inlet (upper right); geologic map of the northern Iniskin Peninsula (bottom), modified from Detterman and Hartsock (1966). Key to map unit abbreviations and stratigraphic order is shown in the middle left. 


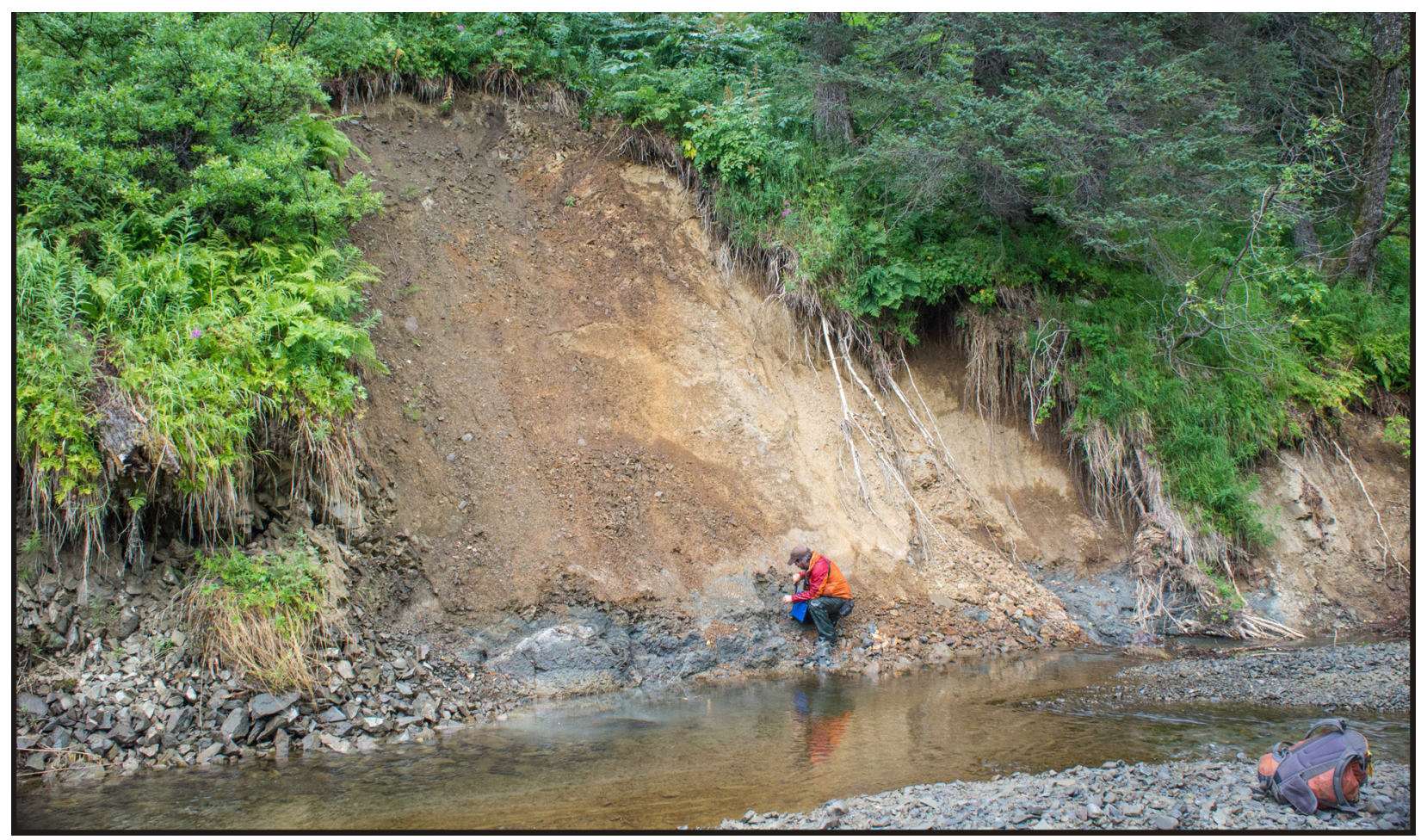

Figure 5-2. Outcrop photo of the oil-stained fault zone. The greenish gray lithology being examined by geologist exhibited moderate to strong hydrocarbon odor, which contrasts with the unstained, indurated, light gray sandstone in rubble at photo left.

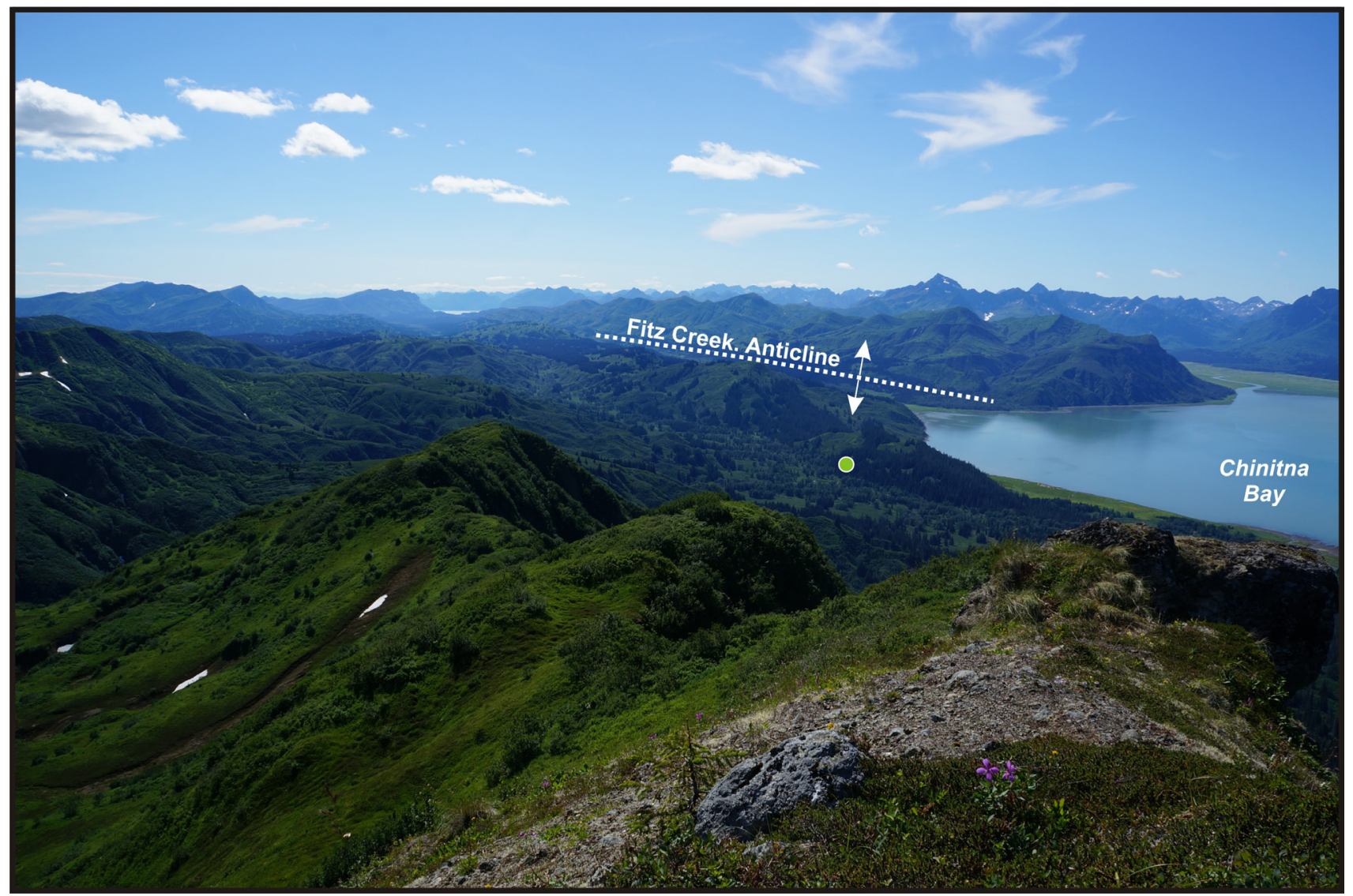

Figure 5-3. View to the southwest illustrating the approximate location of the oil-stained fault zone (green dot) in the southeast-dipping limb of the Fitz Creek anticline. 
Samples were collected for petrographic assessment of sandstone composition and porosity and permeability measurements. Additional samples were retained for hydrocarbon extraction; the organic geochemistry of the hydrocarbons will be compared against existing isotopic and biomarker data from rocks in the lower Tuxedni Group, which are widely regarded as the principal oil-prone source rock in the basin (Magoon and Anders, 1992). The results of these analyses will be published in forthcoming reports.

\section{DISCUSSION}

The discovery of oil-stained rocks on the Iniskin Peninsula builds on the numerous previous indications of an active petroleum system in the region (for example, Magoon, 1994). The recognition of hydrocarbons concentrated in a fault zone is the first outcrop-based evidence that structural deformation is at least locally responsible for creating pore fluid space. This occurrence, although isolated, offers support for previous conjectures regarding the important role of fractures in controlling the location of surface seeps elsewhere on the Iniskin Peninsula (Detterman and Hartsock, 1966). Further, despite the generally low porosity and permeability of the Jurassic section (Helmold and others, 2013), the association of hydrocarbons with intensely fractured rock may indicate the potential for unconventional Mesozoic reservoirs in the subsurface (Gillis and others, 2013; LePain and others, 2013).

The fact that undeformed facies bounding the fault zone are not perceptibly hydrocarbon charged implies that they did not possess sufficient reservoir quality during migration, or that the fault zone was a strongly preferred conduit for fluids. This observation may also suggest that diagenetic cementation predated either the faulting or oil migration or both. The cross faults and associated joints on the Iniskin Peninsula are here interpreted as being related to the development of the large, northeast-trending folds. Map relations suggest at least three episodes of deformation affected the western side of Cook Inlet (Detterman and Hartsock, 1966; Magoon and others, 1980), although the timing of faulting on the Iniskin Peninsula remains poorly constrained. Assessing the timing of this deformation is critical to understanding the petroleum system in this area, particularly with respect to when maturation and migration occurred. Unfortunately, the timing of oil generation remains poorly constrained in many parts of the basin (Magoon, 1994; LePain and others, 2013). Nevertheless, two potential scenarios include: (1) early fault/joint development, followed by later burial into the oil window, driving expulsion, or (2) the source rocks could have matured prior to faulting, with migration pathways only developing during later deformation.

In order to address the relative timing of deformation and oil expulsion/migration, an extensive suite of thermochronology samples were collected across the peninsula. These data may shed light on the timing of cooling and exhumation of the Jurassic stratigraphy. Ultimately, integration of this exhumation record with ongoing structural and stratigraphic studies will yield additional insight into the burial, maturation, uplift/deformation, and migration history of the petroleum system in lower Cook Inlet.

\section{ACKNOWLEDGMENTS}

We thank Rebekah Tsigonis for field assistance and camp support; Rick Stanley (U.S. Geological Survey) and Ken Helmold (Alaska Division of Oil \& Gas) for constructive conversations in the field; Mike Fell (Pathfinder Aviation) for helicopter support; Merril and Marti (Bear Mountain Lodge) for their hospitality; Jack Barber (Alaska Air Taxi); Bald Mountain Air; and David LePain for careful review of this report. The Iniskin Peninsula area mapping project was funded by a substantial contribution from the U.S. Geological Survey STATEMAP Program (award no. G13AC00157).

\section{REFERENCES CITED}

Blasko, D.P., 1976, Oil and gas exploration on the Iniskin Peninsula, Alaska: U.S. Bureau of Mines Open-File Report 7669, $19 \mathrm{p}$.

Detterman, R.L., and Hartsock, J.K., 1966, Geology of the Iniskin-Tuxedni Peninsula region, Alaska: U.S. Geological Survey Professional Paper 512, 78 p., 7 plates.

Gillis, R.J., Maley, M.R., Frohman, R.A., and Peterson, C.S., 2013, Fracture studies in Upper Cretaceous and Upper Jurassic strata on the upper Alaska Peninsula and lower Cook Inlet, in Gillis, R.J., ed., Overview of 2012 field studies-Upper Alaska Peninsula and west side of lower Cook Inlet, Alaska: Alaska Division of Geological \& Geophysical Surveys Preliminary Interpretive Report 2013-1D, p. 13-17.

Helmold, K.P., LePain, D.L., Wilson, M.D., and Peterson, C.S., 2013, Petrology and reservoir potential of Tertiary and Mesozoic sandstones, Cook Inlet, Alaska-A preliminary analysis of outcrop samples collected during 2007-2010 field seasons: Alaska Division of Geological \& Geophysical Surveys Preliminary Interpretive Report 2013-5, 34 p. 
LePain, D.L., Stanley, R.G., and Helmold, K.P., 2013, Geologic framework and petroleum systems of Cook Inlet basin, south-central Alaska, in Stone, D.M., and Hite, D.M., eds., Oil and Gas Fields of the Cook Inlet Basin: American Association of Petroleum Geologists Memoir 104, p. 37-116.

Magoon, L.B., 1994, Tuxedni-Hemlock(!) petroleum system in Cook Inlet, Alaska, U.S.A., in Magoon, L.B., and Dow, W.G., eds., The Petroleum System_From Source to Trap: American Association of Petroleum Geologists Memoir 60, p. 359-370.

Magoon, L.B., and Anders, D.E., 1992, Oil-to-source-rock correlation using carbon-isotopic data and biological marker compounds, Cook Inlet_-Alaska Peninsula, Alaska, in Moldowan, J.M., Albrecht, Pierre, and Philp, R.P., eds., Biological markers in sediments and petroleum: Englewood Cliffs, N.J., Prentice-Hall, p. 241-274.

Magoon, L.B., Griesbach, F.B., and Egbert, R.M., 1980, Nonmarine Upper Cretaceous rocks, Cook Inlet, Alaska: American Association of Petroleum Geologists Bulletin, v. 64, p. 1,259-1,266.

Martin, G.C., 1905, Notes on the petroleum fields of Alaska, in U.S. Geological Survey, Report of progress on investigations of mineral resources in Alaska in 1904: U.S. Geological Survey Bulletin 259, p. 128-129.

Martin, G.C., and Katz, F.J., 1912, A geologic reconnaissance of the Iliamna region, Alaska: U.S. Geological Survey Bulletin 485, 138 p., 2 sheets, scale 1:250,000.

Moffit, F.H., 1927, The Iniskin-Chinitna Peninsula and the Snug Harbor district, Alaska: U.S. Geological Survey Bulletin 789,71 p., 5 sheets, scale 1:250,000. 



\section{CHAPTER 6}

\section{DISCOVERY OF OIL-STAINED SANDSTONE WITHIN THE CHINITNA FORMATION, NORTHERN INISKIN PENINSULA}

Marwan A. Wartes ${ }^{1}$ and Trystan M. Herriott ${ }^{1}$

The potential for Middle and Upper Jurassic sandstone to serve as viable conventional reservoirs in Cook Inlet is poorly known (LePain and others, 2013). The purpose of this report is to announce a newly discovered occurrence of non-fractured, oil-stained Jurassic rocks exposed along the northern shore of the Iniskin Peninsula (fig. 6-1). The new locality² was discovered during a geologic mapping traverse along the south shore of Chinitna Bay (fig. 6-1; see project overview [chapter 1,

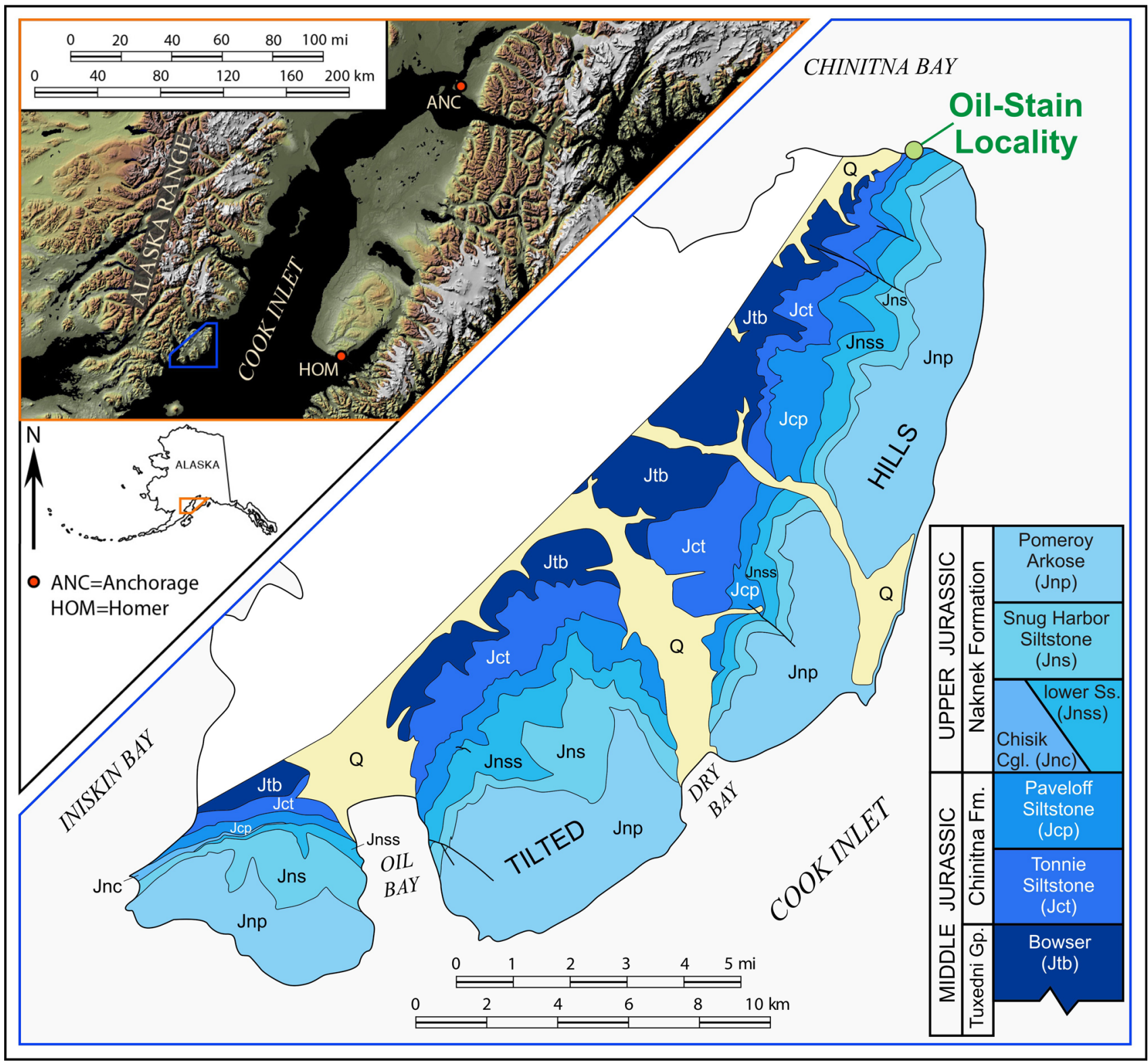

Figure 6-1. Shaded-relief location map of southern Alaska (upper left) and simplified geologic map of the Tilted Hills on the Iniskin Peninsula (modified from Herriott and Wartes [chapter 5, this volume]). Note the location of the oil-stained outcrop discussed in this study. Simplified stratigraphic column (lower right) is modified from Detterman and Hartsock (1966).

${ }^{1}$ Alaska Division of Geological \& Geophysical Surveys, 3354 College Rd., Fairbanks, Alaska 99709-3707; marwan.wartes@alaska.gov; trystan.herriott@alaska.gov

${ }^{2}$ Location coordinates: N59.83472 $;$ W153.01906 ${ }^{\circ}$ (NAD27AK) 
this volume]). The outcrop is part of an east-dipping succession that includes the Middle Jurassic Chinitna Formation and much of the Upper Jurassic Naknek Formation (fig. 6-1). The excellent sea-cliff exposures can be correlated southward into the Tilted Hills (fig. 2-2; chapter 2, this volume).

The oil-stained interval lies within an approximately 100-m-thick sandstone-dominated package mapped as the lower part of the Paveloff Siltstone Member of the Chinitna Formation (figs. 6-1 and 6-2). The moderate to strong hydrocarbon odor was discovered in a sandstone boulder at the base of the outcrop, but is clearly derived from the adjacent cliff. The petroliferous zone is a gray-green- to gray-brown-weathering, very-thick-bedded, poorly sorted, structureless, lithic-rich, coarse-grained sandstone. The lack of apparent intra-bed grading or stratification suggests mass-flow deposition.

Samples of the oil-stained sandstone will undergo routine analysis for porosity and permeability. Thin sections cut from these samples will be evaluated for framework composition, sorting, and cements. These results will add to the growing database of reservoir quality information recently summarized in Helmold and others (2013). Samples were also collected for organic geochemistry and any extracted hydrocarbons will be compared against data from known source rocks (Magoon and Anders, 1992). Results from these follow-up studies will be published in subsequent reports. The presence of sufficient matrix porosity to host migrated oil raises the possibility that processes inhibiting reservoir quality in Jurassic sandstone may not uniformly impact the entire section. Additional reports will explore this unique occurrence and what might control the apparent preservation of modest porosity and permeability.

\section{ACKNOWLEDGMENTS}

We thank Rebekah Tsigonis for field assistance and camp support; Rick Stanley (U.S. Geological Survey) and Ken Helmold (Alaska Division of Oil \& Gas) for constructive conversations in the field; Mike Fell (Pathfinder Aviation) for helicopter support; Merril and Marti (Bear Mountain Lodge) for their hospitality; Jack Barber (Alaska Air Taxi); Bald Mountain Air; and David LePain for careful review of this report. The Iniskin Peninsula area mapping project was funded by a substantial contribution from the U.S. Geological Survey STATEMAP Program (award no. G13AC00157).

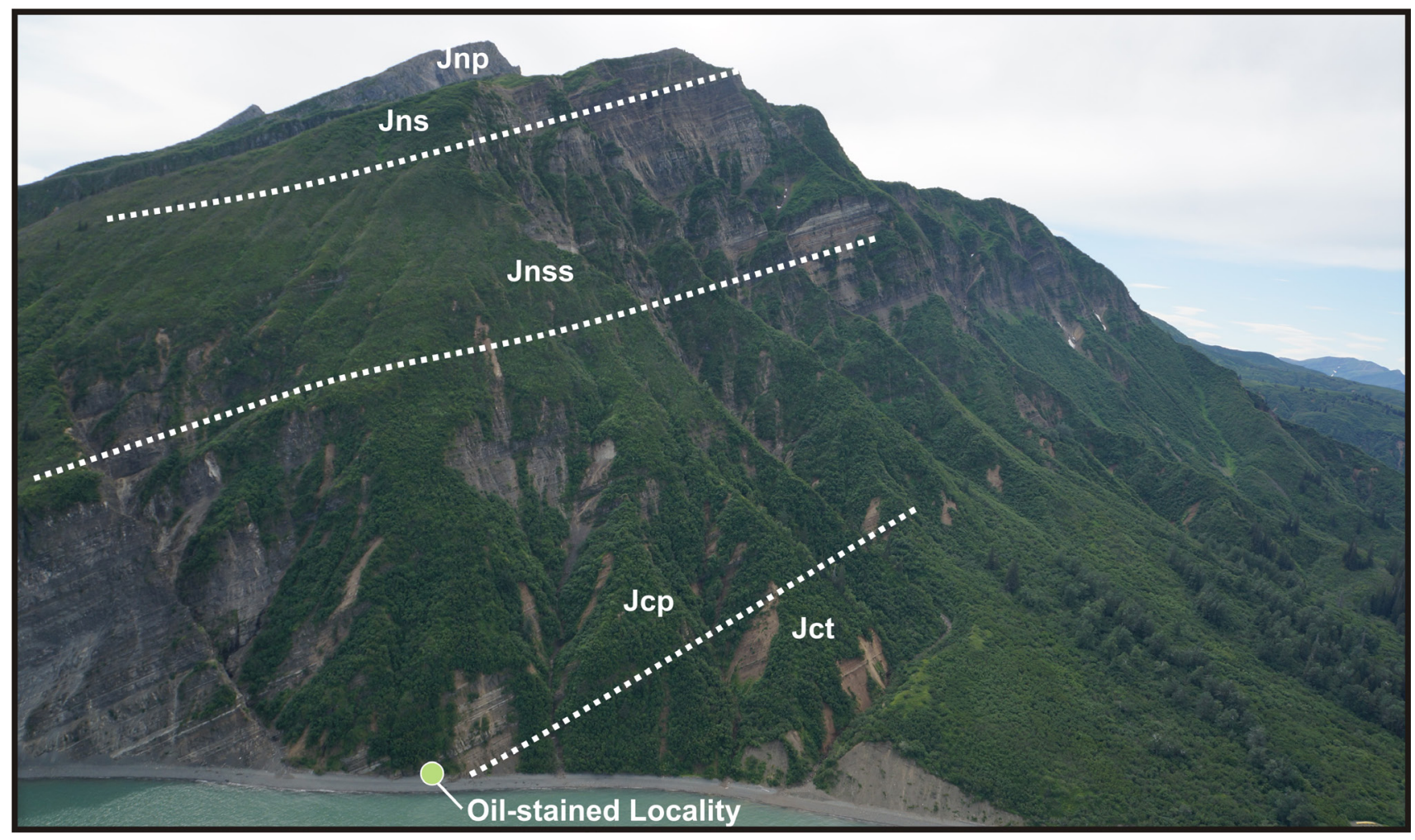

Figure 6-2. Annotated photo of the northern Tilted Hills on the Iniskin Peninsula. View to the south, with the south shore of Chinitna Bay in the foreground. Unit abbreviations for members of the Chinitna Formation: Jct = Tonnie Siltstone, $\mathrm{Jcp}=$ Paveloff Siltstone; members of the Naknek Formation: Jnss = lower sandstone, Jns = Snug Harbor Siltstone, Jnp = Pomeroy Arkose. 


\section{REFERENCES CITED}

Helmold, K.P., LePain, D.L., Wilson, M.D., and Peterson, C.S., 2013, Petrology and reservoir potential of Tertiary and Mesozoic sandstones, Cook Inlet, Alaska-A preliminary analysis of outcrop samples collected during 2007-2010 field seasons: Alaska Division of Geological \& Geophysical Surveys Preliminary Interpretive Report 2013-5, 34 p.

LePain, D.L., Stanley, R.G., and Helmold, K.P., 2013, Geologic framework and petroleum systems of Cook Inlet basin, south-central Alaska, in Stone, D.M., and Hite, D.M., eds., Oil and Gas Fields of the Cook Inlet Basin: American Association of Petroleum Geologists Memoir 104, p. 37-116.

Magoon, L.B., and Anders, D.E., 1992, Oil-to-source-rock correlation using carbon-isotopic data and biological marker compounds, Cook Inlet—Alaska Peninsula, Alaska, in Moldowan, J.M., Albrecht, Pierre, and Philp, R.P., eds., Biological markers in sediments and petroleum: Englewood Cliffs, N.J., Prentice-Hall, p. 241-274. 